\title{
DETERMINATION OF MICRO AND MACRO FACTORS AFFECTING CASH DIVIDEND PAYOUT POLICIES BY PANEL DATA ANALYSIS: A RESEARCH ON BIST 100 INDEX
}

DOI: 10.17261/Pressacademia.2019.1024

JEFA- V.6-ISS.1-2019(1)-p.1-18

Emre Esat Topaloglu ${ }^{1}$, Turhan Korkmaz ${ }^{2}$

${ }^{1}$ Sirnak University, Business Administration, Sirnak, Turkey emresatopal@sirnak.edu.tr, ORCID: 0000-0001-8771-779x

2 Mersin University, Business Administration, Mersin, Turkey. tkorkmaz@mersin.edu.tr, ORCID: 0000-0001-5468-2279

Date Received: January 9, 2019

Date Accepted: March 15, 2019

To cite this document

Topaloglu, E. E., Korkmaz, T. (2019). Determination of micro and macro factors affecting cash dividend payout policies by panel data analysis: A research on BIST 100 index. Journal of Economics, Finance and Accounting (JEFA), V.6(1), p.1-18.

Permemant link to this document: http://doi.org/10.17261/Pressacademia.2019.1024

Copyright: Published by PressAcademia and limited licenced re-use rights only

\section{ABSTRACT}

Purpose - It was aimed to determine the micro and macro factors affecting the dividend policies of firms. Firms in Borsa Istanbul 100 Index, whose shares are traded on a regular basis and which are not active in the financial sector have been analyzed.

Methodology - Relationship between the dividend policies of firms and micro and macro factors have been analyzed using the panel data method. And We used the White's cross section coefficient covariance method in order to account for heteroscedasticity effects.

Findings - A statistically significant and positive relationship was observed between payout ratio and return on assets, financial leverage and market value. Significant and negative relationship was observed between payout ratio and assets structure, growth opportunity, firm size and inflation rate. There was no significant relationship between payout ratio and liquidity ratio, gold price and interest rate.

Conclusion - These findings support bird in the hand, tax effect, signal and agency theories.

Keywords: Dividend, micro factor, macro factor, panel data analysis, BIST 100.

JEL Codes: C33, C82, E44

\section{NAKIT KAR PAYI DAĞITIM POLITIKALARINI ETKILEYEN MIKRO VE MAKRO DEĞiŞKENLERIN PANEL VERi ANALIZi íLE TESPIT EDILMESI: BIST 100 ENDEKSI ÜZERINE BíR ARAŞTIRMA}

\section{ÖZET}

Amaç - Firmaların nakit kar payı dağıtım politikalarına etki eden mikro ve makro faktörlerin belirlenmesi amaçlanmıştır. Borsa İstanbul 100 Endeksi'nde payları devamlı olarak işlem gören ve mali sektörde faaliyet göstermeyen otuz üç firmanın $2010-2016$ dönemindeki verileri incelenmiştir.

Metodoloji - Nakit kar payı dağıtım politikaları ile mikro ve makro faktörler arasındaki ilişki panel veri yöntemi kullanılarak analiz edilmiştir. Yatay kesitler arasındaki farklı hata varyanslarının yanı sıra korelasyon sorununa da çözüm üreten White'ın standart hataların düzeltilmesi yöntemi kullanılmıştır.

Bulgular - Analiz sonucunda, nakit kar payı dağıtım oranı ile aktif karlılık oranı, finansal kaldıraç ve piyasa değeri arasında anlamlı ve pozitif ilişki tespit edilirken; varlık yapısı, büyüme fırsatı, firma büyüklüğü ve enflasyon oranı arasında anlamlı ve negatif ilişki tespit edilmiştir. Likidite oranı, altın fiyatı ve faiz oranı ile nakit kar payı dağıtım oranı arasında ise anlamlı herhangi bir ilişki bulunmamıştır.

Sonuç- Çalışmadan elde edilen bulguların, eldeki kuş, vergi etkisi, sinyal ve temsil maliyeti teorilerini desteklediği belirlenmiştir.

Anahtar Kelimeler: Karpayı, mikro faktör, makro faktör, panel veri analizi, BIST 100.

JEL Kodları: C33, C82, E44. 


\section{Giriş}

Firmaların gerek ulusal gerekse uluslararası piyasalarda varlıklarını sürdürebilmeleri ve rekabet avantajı elde edebilmeleri için yürütmüş oldukları finansman, yatırım ve kar payı dağıtım politikaları önem arz etmektedir. Finansal küreselleşme ile birlikte gelişim ve büyüme süreçlerinin son derece hızlı geliştiği firmalarda, piyasa değerini maksimize edebilmek için elde edilen karın ne kadarının yatırımlarda kullanılacağı ya da hangi oranda hissedarlara kar payı olarak dağıtılacağı ve bu dağıtımın sabit tutarda veya oranda yapılıp yapılmayacağı da kar payı dağıtım politikasının belirlenmesi açısından önemli bir konudur. Firmalar uygulamış oldukları kar payı dağıtım politikaları ile sermaye piyasalarından fon ihtiyaçlarını karşılayabilmekte, yatırımcıları kendilerine çekebilmekte ve piyasa değerlerini artırabilmektedir. Finans literatüründe, kar payı dağıtım politikaları ile firma değeri arasındaki ilişkiyi açıklayan yaklaşım ve teorilerin geliştirildiği temel nitelikte çalışmalar söz konusudur.

Firmaların kar payı dağıtım politikalarına etki eden faktörleri belirleyebilmek için Lintner (1956) tarafından yapılan çalışma, konuya ilişkin gerçekleştirilen öncü çalışmalardan biri konumundadır. Bu çalışma sonrasında, kar payı dağıtım politikasını etkileyen faktörler ile piyasa değerleri arasındaki ilişkiyi açıklamaya yönelik birçok yaklaşım ve teori geliştirmiştir.

Kar payı dağıtım politikalarına ilişkin ilintisizlik teorisi ve eldeki kuş teorisi gibi temel iki görüşün olmasının yanı sıra vergi etkisi teorisi, müşteri etkisi teorisi, sinyal etkisi teorisi ve temsil maliyeti teorisi gibi görüşler de söz konusudur (Ceylan ve Korkmaz, 2017: 298).

İlintisizlik teorisinde, kar payı dağıtım politikası ile firma değeri ve finansman kararları arasında herhangi bir ilişkinin olmadığını öngörmüştür. Diğer bir deyişle teoride, firmanın yatırım kararının ve sermaye yapısının kar payı dağıtım politikasından bağımsız olduğu savunulmaktadır. Teoriye göre firma değeri, varlıkların kazanma gücüne, firmanın risklilik düzeyine ve yatırım politikalarına bağı olarak değişmektedir. İlintisizlik teorisinde yatırımcılar, cari dönemde dağıtılacak kar payı ile gelecek dönemde elde edilecek sermaye kazancı arasında kayıtsız kalmaktadır. Piyasaların etkin olduğu varsayımı altında yatırımcılar, sermaye kazancını sahip oldukları pay senetlerini satarak elde edebilecekleri gibi, firmada kalan karın kar payı olarak dağıtılması durumda ise likidite ihtiyacı içerisinde olmayan yatırımcılar firmanın pay senetlerini satın alabilmektedir. Dolayısıyla yatırımcılar sermaye kazancı ya da kar payı dağıtım kararı arasında yaptıkları tercihler doğrultusunda firmanın kar payı dağıtım politikasını belirleyebilmektedir (Modigliani ve Miller, 1961).

Lintner (1962) ve Gordon (1963) tarafından gerçekleştirilen çalışmalarda geliştirilen eldeki kuş teorisinde, Modigliani ve Miller ilintisizlik teorisinin aksine, kar payı dağıtım politikalarının firma değerini etkilediği öngörülmektedir. Teoriye göre kar payı kazancı eldeki kuşu ifade ederken, sermaye kazancı ise daldaki kuşu temsil etmektedir. Yatırımcıların riskten kaçındıkları dikkate alındığında risk düzeyi daha düşük olan kar payı ödemelerine, riskin daha yüksek olduğu sermaye kazancına göre daha düşük iskonto uyguladıkları söylenebilir (Gürsoy, 2014: 611). Diğer bir deyişle, sermaye kazancı üzerindeki belirsizlik, kar payı kazancı için geçerli olmadığından kar payı kazancı, sermaye kazancına göre daha üstündür.

Vergi etkisi teorisine göre, farklı zamanlarda ortaya çıkan ve farklı vergi oranlarına tabi olan sermaye ve kar payı kazançlarının firma değerini etkilediği görüşü söz konusudur. Firmaların ihtiyaç duydukları fonları otofinansman yoluyla sağlayabilmeleri için birçok ülke kar payı kazancına daha yüksek vergi uygulamaktadır. Böylelikle sermaye birikimi teşvik edilerek otofinansman özendirilmektedir. Dolayısıyla Lintner ve Gordon'un tersine vergi teorisinde, sermaye maliyetini düşürebilmek için kar payı dağıtım oranının azaltılması benimsenmektedir. Diğer taraftan, piyasaların etkin olduğu varsayımı altında vergi uygulamalarının sermaye ya da kar payı kazançları açısından farklılık yaratmadığını belirtmişlerdir. Ancak rasyonel piyasa koşulları dikkate alındığında firma paydaşları açısından vergi etkisinin kar payı politikalarına ve firma değerine herhangi bir etkisinin olmadığı varsayımı gerçeği yansıtmamaktadır (Modigliani ve Miller, 1961).

Kar payı dağıtım politikaları ile firma değeri arasındaki ilişkiye yönelik bir diğer yaklaşım da müşteri etkisi teorisidir. Teoriye göre, kar payı kazancını tercih eden, sermaye kazancını tercih eden ve her iki kazanç arasında kayıtsız kalan yatırımcılar söz konusudur. Yatırımcılar farklı vergilendirme uygulamaları doğrultusunda yatırım yapacakları firmaları belirlemektedir. Sermaye kazancına ilişkin vergi avantajlarından faydalanmak isteyen yatırımcılar, nakit temettü ödemesi yapan firmalara yatırım yapmamakta ya da mevcut pay senetlerini satmaktadırlar. Böylelikle yatırımcılar, vergi uygulamaları doğrultusunda firmalara yatırım yapmakta ve firmaların piyasa değerlerini etkilemektedir (Diacogiannis, 1993).

Sinyal etkisi teorisine göre, kar payı dağıtım politikalarındaki değişimler, firmaların mevcut ve gelecekteki karlılık durumları hakkında başta yatırımcılar olmak üzere piyasalara da bilgi sunmaktadır. Firmalar, yatırım politikası, sermaye yapısı ve kar payı dağıtım kararlarına ilişkin gerçekleştirdikleri uygulamalar neticesinde, bilgi düzeylerindeki farklılıklardan dolayı ortaya çıkan asimetrik bilgi sorununu ortadan kaldırarak, piyasada ve yatırımcılarda olumlu bir algı oluşturabilmektedir. Bu durum da firmanın piyasa değerini etkilemektedir. Kar payı dağıtım oranının düşük olduğu firmalarda, yatırımları finanse edebilmek için 
otofinansman kararı alınabilmektedir. Dönem boyunca yürütülen faaliyetler sonucu elde edilen kazancın pay sahiplerine dağıtılmayıp, net bugünkü değeri pozitif olarak belirlenen yatırımlara yönlendirilmesi, yatırımcılarda firmanın mali durumunun yetersiz ve iyi olmadığı gibi yanlış algılara yol açabilmektedir. Buna karşın daha yüksek kar payı dağıtımı yapacağını piyasalara aktaran firmalar için yatıııcılar, karlılık düzeylerinin yükseldiğini, mali durumun iyi olduğunu ve bu nedenle daha yüksek oranda kar payı dağıımının yapıldığını varsaymaktadır. Dolayısıyla yatırımcılar, firmaların piyasaya ilettikleri sinyaller doğrultusunda pay senetlerine yatırım kararı almaktadırlar (Harris ve Raviv, 1991; Van Horne ve Wachowicz, 1997).

Temsil maliyeti teorisi, firma yöneticileri, pay sahipleri ve firmaya borç verenler arasındaki çıkar çatışmaları sonucu ortaya çıkan maliyetleri içermektedir. Pay sahipleri ve yöneticiler firmadaki konum ve güçlerini kullanarak firma değerini maksimize etmek yerine, kişisel çıkarlarını maksimize etme çabasına girmektedir. Diğer bir ifadeyle, firma içerisindeki bu gruplar firma kazancının kendilerine aktarılmasını talep etmektedirler. Pay sahipleri, firmanın karlılı̆ı yüksek ve net bugünkü değerleri pozitif olan yatırımlara yönelerek daha yüksek oranda kar payı dağıtımı gerçekleştirmelerini istemektedirler. Kar payı dağıtım oranının yüksek olduğu firmalarda likidite düşük olmakta ve yöneticiler devamlı olarak yeni yatırım fırsatı arayışına girmektedir. Kaynakların devamlı olarak yeni yatırımlara aktarıldığı firmalarda yöneticiler, bu fonları kendi çıkarları doğrultusunda kullanamamaktadır. Bu durum da firma içerisindeki temsil maliyetleri azalmaktadır. Dolayısıyla kar payı dağıım oranının yüksek olduğu firmalarda yöneticiler, kaynakları verimli ve net bugünkü değeri pozitif olan yatırımlara yönlendirerek, diğer koşullar sabit varsayıldığında, firma değerini yükseltebilmektedir. Kar payı dağıtım oranının yüksek olması, pay sahiplerinin çıkarlarına daha fazla hizmet etmektedir. Dolayısıyla firmaya borç verenler açısından kar payı dağıtım oranının düşük olması tercih edilmektedir. Bu bağlamda borç verenler, firmaya kaynak aktarımı yaparken, firmanın kar payı dağıtım politikalarına kısıtlama getirerek, kendi menfaatlerini koruyabilmektedir (Jensen ve Meckling, 1976).

Kar payı dağıtım politikası ile firma değeri arasındaki ilişkiye yönelik olarak geliştirilen teoriler doğrultusunda, firmalar açısından kar payı dağıtım politikalarının en az yatırım ve finansman politikaları kadar önemli olduğunu söylemek mümkündür. Dolayısıyla firmaların kar payı dağıtım politikalarına etki eden mikro ve makro faktörlerin belirlenmesi gerekmektedir. Bu amaçla çalışmada, Borsa İstanbul 100 Endeksinde 2010-2016 döneminde pay senetleri devamlı olarak işlem gören firmaların nakit kar payı dağıtım politikaları ile mikro ve makro faktörler arasındaki ilişki panel veri analizi yardımıyla incelenmiştir. Çalışmada ilk olarak konuya ilişkin ulusal ve uluslararası yazında yapılmış önceki çalışmaların yer aldığı literatür taramasına yer verilmiştir. Ardından çalışmanın metodolojik bilgilerine ve gerçekleştirilen analiz neticesinde elde edilen bulgulara değinilmiştir. Sonrasında ise sonuç ve değerlendirmeler açıklanarak, daha sonraki çalışmalara yönelik öneriler sunulmuştur. Bu çalışmada, payları Borsa İstanbul'da işlem gören ve BIST 100 endeksine dâhil olan firmaların nakit kar payı dağıtım politikalarına etki eden mikro ve makro faktörler tespit edilmeye çalışılmıştır. Çalışmada nakit kar payı dağıtım oranına odaklanılması, kar payı dağıtım politikasına etki eden mikro ve makro faktörlerin bir arada incelenmesi gibi faktörler doğrultusunda çalışmanın özgünlük sunduğu ve literatüre katkı sağladığı düşünülmektedir.

\section{KONUYA İLiŞKIN OLARAK GERÇEKLEŞTIRILEN ÖNCEKI ÇALIŞMALARDA ELDE EDILEN ARAŞTIRMA BULGULARI}

Nakit kar payı dağıtım politikasına etki eden mikro faktörlere ilişkin olarak ulusal ve uluslararası literatürde birçok çalışma söz konusudur. Ancak kar payı dağıtım politikasına etki eden makro faktörlerin incelendiği çalışma sayısı sınırlıdır. Gelişmekte olan ülke konumunda olan Türkiye'nin majör borsa endeksinin araştırmaya konu olması doğrultusunda literatür taraması ağırlıklı olarak gelişmekte olan ülkeler kapsamında gerçekleştirilmiştir. Bu bağlamda konuya ilişkin olarak gerçekleştirilen önceki çalışmaların kapsamı ve ulaşılan bulguların yer aldığı literatür taraması kronolojik sıralama esas alınarak aşağıda Tablo 1'de açıklanmıştır.

Tablo 1: Kar Payı Dağıtım Politikasını Etkileyen Faktörlere illişkin Literatür Özeti

\begin{tabular}{|c|c|c|c|c|c|c|}
\hline YII & Yazarlar & Ülke & Kapsam & Yöntem & Değişkenler & Bulgular \\
\hline 2006 & $\begin{array}{l}\text { Amidu ve } \\
\text { Abor }\end{array}$ & Gana & $\begin{array}{l}\text { 1998-2003 } \\
\text { Dönemi } \\
\text { Borsada işlem } \\
\text { gören } 22 \text { firma }\end{array}$ & $\begin{array}{l}\text { En küçük kareler } \\
\text { yöntemi ve panel } \\
\text { veri analizi }\end{array}$ & $\begin{array}{l}\text { - Kar payı dağıtım oranı, } \\
\text { - Karlılık, } \\
\text { - Serbest nakit akışı, } \\
\text { - } \text { Vergi oranı, } \\
\text { - } \text { Büyüme, } \\
\text { - Holdingleşme, } \\
\text { - } \text { Risk } \\
\text { - Piyasa değeri/defter } \\
\text { değeri }\end{array}$ & $\begin{array}{l}\text { Kar payı dağıtım oranı ile karlılık, serbest } \\
\text { nakit akışı ve vergi arasında istatistikî olarak } \\
\text { anlamlı ve pozitif ilişki belirlenirken, büyüme, } \\
\text { holdingleşme, risk ve piyasa değeri/defter } \\
\text { değeri ile kar payı dağıtım oranı arasında } \\
\text { istatistikî olarak anlamlı ve negatif ilişki } \\
\text { belirlenmiştir. }\end{array}$ \\
\hline 2007 & Al & Amman & $1992-2002$ & Tobit regresyon & $\begin{array}{l}\text { - Kar payı dağıtım oranı } \\
\text { - Firma büyüklüğü }\end{array}$ & $\begin{array}{l}\text { Kar payı dağıtım oranı ile firma büyüklüğüu, } \\
\text { yaşı ve karlılık arasında istatistikî olarak }\end{array}$ \\
\hline
\end{tabular}




\begin{tabular}{|c|c|c|c|c|c|c|}
\hline & Malkawi & & $\begin{array}{l}\text { Dönemi } \\
\text { Borsada farklı } \\
\text { sektörlerde işlem } \\
\text { gören firmalar }\end{array}$ & analizi & $\begin{array}{l}\text { : Firma yaşı } \\
\text { - Karlıık } \\
\text { - Finansal kaldıraç }\end{array}$ & $\begin{array}{l}\text { anlamlı ve pozitif ilişki, finansal kaldıraç ile } \\
\text { kar payı dağııı oranı arasında anlamlı ve } \\
\text { negatif ilişki tespit edilmiştir. }\end{array}$ \\
\hline 2008 & $\begin{array}{l}\text { Ahmed ve } \\
\text { Javid }\end{array}$ & Pakistan & $\begin{array}{l}\text { 2001-2006 } \\
\text { dönemi } \\
\text { Karachi } \\
\text { Borsası'nda işlem } \\
\text { gören } 320 \text { firma }\end{array}$ & $\begin{array}{l}\text { Dinamik panel } \\
\text { veri modeli }\end{array}$ & $\begin{array}{l}\text { : Kar payı dağııım oranı } \\
\text { : Karllıı } \\
\text { - Serbest nakit akışı } \\
\text { - Firma büyüklüğü } \\
\text { - Yatırım firsatları } \\
\text { : Sahiplik yapısı } \\
\text { : Likidite } \\
\text { - Büyüme fırsatı } \\
\text { - } \text { Finansal kaldıraç }\end{array}$ & $\begin{array}{l}\text { Iststikrarlı ve karlıı düzeyi yüksek olan } \\
\text { firmaların daha fazla serbest nakit akışına ve } \\
\text { kar payı dağıı oranına sahip oldukları } \\
\text { belirlenmesinin yanı sıra, firma büyüklüğü ve } \\
\text { yatıım fırsatları ile kar payı dağııı oranı } \\
\text { arasında anlamlı ve negatif ilişsi tespit } \\
\text { edilirken, sahiplik yapısı ve likidite ile anlamlı } \\
\text { ve pozitif ilişki tespit edilmiştir. Bu karşın } \\
\text { çalışmada, büyüme fırsatı ve finansal kaldıraç } \\
\text { ile kar payı dağııım oranı arasında anlamlı bir } \\
\text { ilişski bulunamamıştır. }\end{array}$ \\
\hline 2008 & $\begin{array}{l}\text { Anil ve } \\
\text { Kapoor }\end{array}$ & Hindistan & $\begin{array}{l}\text { 2000-2006 } \\
\text { dönemi } \\
\text { Hindistan'da } \\
\text { faaliyet } \\
\text { gösteren } \\
\text { teknoloji } \\
\text { firmaları }\end{array}$ & $\begin{array}{l}\text { En küçü̈k kareler } \\
\text { yöntemi ve panel } \\
\text { veri analizi }\end{array}$ & 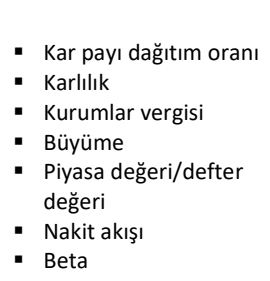 & $\begin{array}{l}\text { Karlııı, kurumlar vergisi, büyüme ve piyasa } \\
\text { değeri/defter değeri ile kar payı dağıtım } \\
\text { oranı arasında anlamlı bir ilişki } \\
\text { bulunamazken, nakit akışı ve beta ile kar payı } \\
\text { dağıtım oranı arasında ise anlamlı ilişki } \\
\text { bulunmuştur. }\end{array}$ \\
\hline 2010 & Gill vd. & ABD & $\begin{array}{l}\text { Amerika Birleşik } \\
\text { Devletleri'nde } \\
\text { hizmet ve imalat } \\
\text { sektöründe } \\
\text { faaliyet } \\
\text { gösteren } 266 \\
\text { firma }\end{array}$ & OLS regresyon & $\begin{array}{l}\text { - Kar payı dağııı oranı } \\
\text { - Aktif karlııı oranı } \\
\text { - Büyüme fırsatı } \\
\text { - Vergi } \\
\text { - Endüstri } \\
\text { - Nakit akımı } \\
\text { - Piyasa değeri/defter } \\
\quad \text { değeri } \\
\text { - Finansal kaldıraç oranı }\end{array}$ & $\begin{array}{l}\text { Aktif karlıık oranı ve büyüme fırsatı ile kar } \\
\text { payı dağıım oranı arasında anlamlı ve } \\
\text { negatif ilişkinin varlığı ortaya çıkarııırken, } \\
\text { vergi ve endüstri ile kar payı dağıtım oranı } \\
\text { arasında ise anlamlı ve pozitif ilişkinin varlığı } \\
\text { ortaya çıkarıımıştır. Diğer taraftan çalışmada, } \\
\text { nakit akımı, piyasa değeri/defter değeri ve } \\
\text { finansal kaldıraç oranı ile kar payı dağıım } \\
\text { oranı arasında anlamlı herhangi bir ilişki } \\
\text { bulunamamıştır }\end{array}$ \\
\hline 2010 & $\begin{array}{l}\text { Afza ve } \\
\text { Mirza }\end{array}$ & Pakistan & $\begin{array}{l}\text { 2005-2007 } \\
\text { Dönemi Borsada } \\
\text { işlem gören } \\
\text { firmalar }\end{array}$ & $\begin{array}{l}\text { En küçük kareler } \\
\text { regresyon analizi }\end{array}$ & $\begin{array}{l}\text { - Kar payı dağııı } \\
\text { ödemeleri } \\
\text { - Sahiplik yapısı } \\
\text { - Yönetim yapısı } \\
\text { - Finansal kaldıraç oranı } \\
\text { - } \text { Firma büyüklüğü } \\
\text { - Nakit akımı } \\
\text { - Serbest nakit akışı } \\
\text { - Karlııı }\end{array}$ & $\begin{array}{l}\text { Analiz neticesinde, kar payı dağııım } \\
\text { ödemeleri ile sahiplik ve yönetim yapısı, } \\
\text { finansal kaldıraç oranı, firma büyüklüğü ve } \\
\text { nakit akımı arasında istatistikî olarak anlamlı } \\
\text { ve negatif ilişki tespit edilirken, serbest nakit } \\
\text { akışı ve karlılık ile kar payı dağıtım oranı } \\
\text { arasında anlamlı ve pozitif ilişki tespit } \\
\text { edilmiştir. }\end{array}$ \\
\hline 2011 & Imran & Pakistan & $\begin{array}{l}\text { 1996-2008 } \\
\text { Dönemi } \\
\text { Mühendislik } \\
\text { sektöründe } \\
\text { faaliyet gösteren } \\
\text { ve Karachi } \\
\text { Borsası'nda } \\
\text { işlem gören } 36 \\
\text { firma }\end{array}$ & $\begin{array}{l}\text { En } \\
\text { küçük } \\
\text { kareler } \\
\text { yönte } \\
\text { mi ve } \\
\text { panel } \\
\text { veri } \\
\text { analizi }\end{array}$ & $\begin{array}{l}\text { - Kar payı dağııı oranı } \\
\text { - Geçmiş yıl kar payı } \\
\text { dağııı oranı, } \\
\text { - Hisse başı kazanç } \\
\text { - Karlıık } \\
\text { - Büyüme fırsatı } \\
\text { - Firma büyüklüğü } \\
\text { - Nakit akımları } \\
\text { - Likidite oranı }\end{array}$ & $\begin{array}{l}\text { Kar payı dağııı oranı ile geçmiş yıl kar payı } \\
\text { dağııı oranı, hisse başı kazanç, karııı } \\
\text { büyüme fırsatı ve firma büyüklüğü arasında } \\
\text { anlamlı ve pozitif ilişki tespit edilirken, kar } \\
\text { payı dağıtım oranı ile nakit akımları arasında } \\
\text { ise anlamlı ve negatif ilişki tespit edilmiştir. } \\
\text { Buna karşın çalışmada, likidite oranı ile kar } \\
\text { payı dağıım oranı arasında ise anlamlı bir } \\
\text { ilişki bulunamamıştır. }\end{array}$ \\
\hline 2011 & Al Shubiri & Ürdün & 2005-2009 & $\begin{array}{l}\text { Tobit } \\
\text { ve }\end{array}$ & $\begin{array}{l}\text { - Kar payı dağıı̆ım oranı } \\
\text { - Finansal kaldıraç oranı }\end{array}$ & $\begin{array}{l}\text { Kar payı dağııı oranı ile finansal kaldıraç } \\
\text { oranı, sahiplik yapısı, firma riski ve varlık }\end{array}$ \\
\hline
\end{tabular}




\begin{tabular}{|c|c|c|c|c|c|c|}
\hline & & & $\begin{array}{l}\text { Dönemi } \\
\text { Borsada işlem } \\
\text { gören firmalar }\end{array}$ & $\begin{array}{l}\text { Logit } \\
\text { regres } \\
\text { yon } \\
\text { yönte } \\
\text { mleri }\end{array}$ & $\begin{array}{l}\text { - Sahiplik yapısı } \\
\text { - } \text { Firma riski } \\
\text { - Varlık yapısı } \\
\text { - Karlııık } \\
\text { - Büyüme fırsatı } \\
\text { - Serbest nakit akışı }\end{array}$ & $\begin{array}{l}\text { yapısı arasında istatistikî olarak anlamlı ve } \\
\text { negatif ilişki belirlenirken, karlıık, büyüme } \\
\text { fırsatı ve serbest nakit akışı ile kar payı } \\
\text { dağıtım oranı arasında ise anlamlı ve pozitif } \\
\text { ilişki belirlenmiştir. }\end{array}$ \\
\hline 2012 & Patra vd. & $\begin{array}{c}\text { Yunanista } \\
\mathrm{n}\end{array}$ & $\begin{array}{l}\text { Mali sektör } \\
\text { dışında faaliyet } \\
\text { gösteren } 63 \\
\text { firma }\end{array}$ & $\begin{array}{l}\text { Dinami } \\
\mathrm{k} \text { panel } \\
\text { veri } \\
\text { modeli }\end{array}$ & $\begin{array}{l}\text { - Kar payı dağıtım oranı } \\
\text { - ROE (Özsermaye } \\
\text { Karlılık Oranı) } \\
\text { - Firma büyüklüğü } \\
\text { - Likidite oranı } \\
\text { - Yatıım firsatı } \\
\text { - Finansal kaldıraç } \\
\text { Firma riski }\end{array}$ & $\begin{array}{l}\text { Analiz neticesinde ROE, firma büyüklüğü ve } \\
\text { likidite oranı ile kar payı dağıtım oranı } \\
\text { arasında anlamlı ve pozitif ilişkinin varlığı } \\
\text { ortaya çıkarıırken, yatııı fırsatı, finansal } \\
\text { kaldıraç ve firma riski ile kar payı dağıtım } \\
\text { oranı arasında ise anlamlı ve negatif ilişkinin } \\
\text { varlığı ortaya çıkarılmıştır. }\end{array}$ \\
\hline 2012 & Mehta & $\begin{array}{l}\text { Birleşik } \\
\text { Arap } \\
\text { Emirlikleri }\end{array}$ & $\begin{array}{l}\text { 2005-2009 } \\
\text { Dönemi } \\
\text { Abu Dhabi } \\
\text { Borsası'nda } \\
\text { işlem gören ve } \\
\text { farklı } \\
\text { sektörlerde } \\
\text { faaliyet gösteren } \\
\text { firmaları }\end{array}$ & $\begin{array}{l}\text { Korela } \\
\text { syon } \\
\text { ve } \\
\text { çoklu } \\
\text { regres } \\
\text { yon } \\
\text { analizi }\end{array}$ & $\begin{array}{l}\text { - Kar payı dağıııı oranı } \\
\text { - } \text { ROEnansal kaldıraç oranı } \\
\text { - Fiyat/kazanç oranı } \\
\text { - Kar payı dağııı oranı } \\
\text { - ROA (Aktif Karlıık } \\
\text { Oranı) } \\
\text { - Hisse başı kazanç } \\
\text { - Likidite oranı }\end{array}$ & $\begin{array}{l}\text { Firma büyüklüğü ile kar payı dağııı oranı } \\
\text { arasında pozitif ilişki belirlenirken, ROE ve } \\
\text { risk ölçütü olarak ele alınan fiyat/kazanç } \\
\text { oranı ile kar payı dağııı oranı arasında ise } \\
\text { negatif ilişki belirlenmiştir. Buna karşın ROA, } \\
\text { hisse başı kazanç, likidite ve finansal kaldıraç } \\
\text { oranı ile kar payı dağıtım oranı arasında } \\
\text { anlamlı bir ilişki tespit edilmemiştir. }\end{array}$ \\
\hline 2013 & $\begin{array}{l}\text { Komratta } \\
\text { napanya }\end{array}$ & Tayland & $\begin{array}{l}\text { 2006-2010 } \\
\text { Dönemi } \\
\text { Borsada pay } \\
\text { senetleri işlem } \\
\text { gören } 435 \text { firma }\end{array}$ & $\begin{array}{l}\text { Tobit } \\
\text { regres } \\
\text { yon } \\
\text { analizi }\end{array}$ & 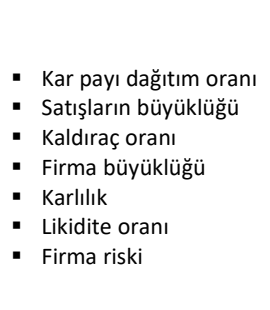 & $\begin{array}{l}\text { Kar payı dağıtım oranı ile yatırım fırsatları, } \\
\text { satışların büyüklüğü ve kaldıraç oranı } \\
\text { arasında istatistikî olarak anlamlı ve negatif } \\
\text { ilişki tespit edilirken, firma büyüklüğü ile kar } \\
\text { payı dağııım oranı arasında anlamlı ve pozitif } \\
\text { ilişki tespit edilmiştir. Ayrıca çalışmada, kar } \\
\text { payı dağıtım oranı ile karıııı, likidite oranı ve } \\
\text { firma riski arasında istatistikî olarak anlamlı } \\
\text { herhangi bir ilişki bulunmamıştır. }\end{array}$ \\
\hline 2013 & Uwuigbe & Nijerya & $\begin{array}{l}\text { 2006-2011 } \\
\text { dönemi } \\
\text { Borsada pay } \\
\text { senetleri işlem } \\
\text { gören } 50 \text { firma }\end{array}$ & $\begin{array}{l}\text { En } \\
\text { küçük } \\
\text { kareler } \\
\text { yönte } \\
\text { mi ve } \\
\text { panel } \\
\text { veri } \\
\text { analizi }\end{array}$ & $\begin{array}{l}\text { - Kar payı dağııım oranı } \\
\text { - ROE } \\
\text { - Firma büyüklüğü } \\
\text { - Finansal kaldıraç } \\
\text { Yönetim kurulu } \\
\text { bağımsızığı }\end{array}$ & $\begin{array}{l}\text { Analiz neticesinde, ROE, firma büyüklüğü ve } \\
\text { yönetim kurulu bağımsızlığı ile kar payı } \\
\text { dağııım oranı arasında anlamlı ve pozitif ilişki } \\
\text { belirlenirken, finansal kaldıraç ile kar payı } \\
\text { dağı̆ım oranı arasında ise anlamlı ve negatif } \\
\text { ilişki belirlenmiştir. }\end{array}$ \\
\hline 2013 & $\begin{array}{l}\text { Musiega } \\
\text { vd. }\end{array}$ & Kenya & $\begin{array}{l}\text { 2007-2011 } \\
\text { dönemi } \\
\text { Nairobi } \\
\text { Borsası'nda } \\
\text { işlem gören ve } \\
\text { mali sektörde } \\
\text { faaliyet } \\
\text { göstermeyen } 50 \\
\text { firma }\end{array}$ & $\begin{array}{l}\text { Tanıml } \\
\text { ayıcı } \\
\text { istatisti } \\
\text { k ve } \\
\text { çoklu } \\
\text { regres } \\
\text { yon } \\
\text { analizi }\end{array}$ & $\begin{array}{l}\text { - Kar payı dağııım oranı } \\
\text { - ROE } \\
\text { - Mevcut kazançlar } \\
\text { Büyüme fırsatları }\end{array}$ & $\begin{array}{l}\text { ROE, mevcut kazançlar ve büyüme firsatları } \\
\text { ile kar payı dağıım oranı arasında anlamlı ve } \\
\text { pozitif ilişki tespit edilmiştir. }\end{array}$ \\
\hline
\end{tabular}




\begin{tabular}{|c|c|c|c|c|c|c|}
\hline 2014 & Yıldız vd. & Türkiye & $\begin{array}{l}\text { 2003-2010 } \\
\text { dönemi } \\
\text { Borsa İstanbul } \\
\text { sanayii } \\
\text { sektöründe } \\
\text { faaliyet } \\
\text { gösteren } 118 \\
\text { firma }\end{array}$ & $\begin{array}{l}\text { En küçük kareler } \\
\text { yöntemi ve panel veri } \\
\text { analizi }\end{array}$ & $\begin{array}{l}\text { - Kar payı dağıtım } \\
\text { - } \text { oranı } \\
\text { - Karlııı } \\
\text { - Büyüme fırsatları } \\
\text { - Firma büyüklüğü } \\
\text { - Halka açıklık oranı } \\
\text { - Sahiplik yapısı } \\
\text { - Finansal kaldıraç } \\
\text { - Vergi oranı } \\
\text { - Yatırımlar } \\
\text { - Likidite oranı } \\
\text { - Yönetim } \\
\text { - bağımsızı̆ı } \\
\text { - Serbest nakit akışı } \\
\text { - Faaliyet riskleri }\end{array}$ & $\begin{array}{l}\text { Kar payı dağıtım politikaları ile vergi, karlılık, } \\
\text { büyüme fırsatları, firma büyüklüğü ve likidite } \\
\text { arasında istatistikî olarak anlamlı ve pozitif } \\
\text { ilişki tespit edilirken, finansal kaldıraç ile } \\
\text { anlamlı ve negatif ilişki tespit edilmiştir. buna } \\
\text { karşın halka açıklık oranı, yatırım, sahiplik } \\
\text { yapısı, faiz, vergi ve amortisman öncesi kar } \\
\text { marjı ve nakit akışı ile kar payı dağıtım } \\
\text { politikaları arasında istatistiki olarak } \\
\text { herhangi bir ilişki tespit edilmemiştir. }\end{array}$ \\
\hline & & & $2009-2013$ & & & \\
\hline 2014 & $\begin{array}{l}\text { Sanjari ve } \\
\text { Zarei }\end{array}$ & İran & $\begin{array}{l}\text { dönemi } \\
\text { Tahran } \\
\text { Borsası'nda pay } \\
\text { senetleri işlem } \\
\text { gören firmalar }\end{array}$ & $\begin{array}{l}\text { Korelasyon ve çoklu } \\
\text { regresyon analizi }\end{array}$ & $\begin{array}{l}\text { - Kar payı dağıtım } \\
\text { - } \text { ROAanı } \\
\text { - } \text { Büyüme fırsatı } \\
\text { - Finansal kaldıraç } \\
\text { - } \text { Firma büyüklüğü } \\
\text { - Likidite oranı }\end{array}$ & $\begin{array}{l}\text { Finansal kaldıraç, firma büyüklüğü ve likidite } \\
\text { ile kar payı dağıtım oranı arasında anlamlı ve } \\
\text { pozitif ilişki belirlenirken, büyüme ve ROA ile } \\
\text { kar payı dağıtım oranı arasında anlamlı ve } \\
\text { negatif ilişki belirlenmiştir. }\end{array}$ \\
\hline 2015 & Kuzucu & Türkiye & $\begin{array}{l}\text { 2006-2013 } \\
\text { dönemi } \\
\text { Pay senetleri } \\
\text { Borsa } \\
\text { İstanbul'da } \\
\text { işlem gören } 142 \\
\text { firma }\end{array}$ & $\begin{array}{l}\text { Panel veri analiz } \\
\text { yöntemi }\end{array}$ & $\begin{array}{l}\text { - Kar payı dağıtım } \\
\text { - } \text { Oranı } \\
\text { - Käyüme oranı } \\
\text { - Finansal kaldıraç } \\
\text { - Firma büyüklüğü } \\
\text { - Fiyat/kazanç oranı } \\
\text { - Firma yaşı }\end{array}$ & $\begin{array}{l}\text { Kar payı dağıtım oranı ile büyüme oranı, } \\
\text { karlılık ve finansal kaldıraç arasında istatistikî } \\
\text { olarak anlamlı ve negatif ilişkinin varlığı } \\
\text { ortaya çıkarıırken; firma büyüklüğü, } \\
\text { fiyat/kazanç oranı ve firma yaşı ile kar payı } \\
\text { dağıtım oranı arasında ise anlamlı ve pozitif } \\
\text { ilişkinin varlığı ortaya çıkarılmıştır. }\end{array}$ \\
\hline 2016 & $\begin{array}{l}\text { Yusof ve } \\
\text { Ismail }\end{array}$ & Malezya & $\begin{array}{l}\text { 2006-2010 } \\
\text { dönemi } \\
\text { Borsada işlem } \\
\text { gören } 147 \text { firma }\end{array}$ & $\begin{array}{l}\text { En küçük kareler } \\
\text { yöntemi ve panel veri } \\
\text { analizi }\end{array}$ & $\begin{array}{l}\text { - Kar payı dağıtım } \\
\text { - Hisse başı kazanç } \\
\text { - Serbest nakit } \\
\text { akımı } \\
\text { - Finansal kaldıraç } \\
\text { - Büyüme fırsatı } \\
\text { - Firma büyüklüğü } \\
\text { - Sahiplik yapısı } \\
\text { - Risk } \\
\text { - Gecikmeli kar payı } \\
\text { dağıtımı }\end{array}$ & $\begin{array}{l}\text { Hisse başı kazanç, firma büyüklüğü ve yatırım } \\
\text { fırsatı ile kar payı dağıtım politikası arasında } \\
\text { anlamlı ve pozitif ilişki tespit edilirken, } \\
\text { finansal kaldıraç ve sahiplik yapısı ile kar payı } \\
\text { dağıtım politikası arasında ise anlamlı ve } \\
\text { negatif ilişki tespit edilmiştir. }\end{array}$ \\
\hline 2016 & Banerjee & Hindistan & $\begin{array}{l}\text { 2010-2014 } \\
\text { dönemi } \\
4 \text { teknoloji } \\
\text { firması }\end{array}$ & Çoklu regresyon analizi & $\begin{array}{l}\text { - Kar payı dağıtım } \\
\text { oranı } \\
\text { - Finansal kaldıraç } \\
\text { - Fiyat/kazanç oranı } \\
\text { - ROE }\end{array}$ & $\begin{array}{l}\text { Kar payı dağıtım oranı ile finansal kaldıraç, } \\
\text { fiyat/kazanç oranı ve ROE arasında anlamlı } \\
\text { ve pozitif ilişkinin varlığı ortaya çıkarılmıştır. }\end{array}$ \\
\hline 2016 & $\begin{array}{l}\text { Labhane } \\
\text { ve } \\
\text { Mahakud }\end{array}$ & Hindistan & $\begin{array}{l}\text { Borsada pay } \\
\text { senetleri } \\
\text { devamlı olarak } \\
\text { işlem gören } \\
\text { firmalar }\end{array}$ & $\begin{array}{l}\text { En küçük kareler } \\
\text { yöntemi ve panel veri } \\
\text { analizi }\end{array}$ & $\begin{array}{l}\text { - Kar payı dağıtım } \\
\text { - } \text { ROA } \\
\text { - Vergi oranı } \\
\text { - Yatırım fırsatı } \\
\text { - Finansal kaldıraç } \\
\text { - Varlık yapısı } \\
\text { - Firma riski } \\
\text { - Firma büyüklüğü }\end{array}$ & $\begin{array}{l}\text { Kar payı dağıtım oranı ile likidite, ROA ve } \\
\text { firma büyüklüğü arasında anlamlı ve pozitif } \\
\text { ilişki tespit edilirken, yatırım fırsatı, finansal } \\
\text { kaldıraç, varlık yapısı, firma riski ve vergi ile } \\
\text { kar payı dağıtım oranı arasında anlamlı ve } \\
\text { negatif ilişki tespit edilmiştir. Buna karşın } \\
\text { çalışmada, kar payı dağıtım oranı ile serbest } \\
\text { nakit akışı arasında anlamlı herhangi bir ilişki } \\
\text { bulunamamıştır. }\end{array}$ \\
\hline 2016 & Sheikh vd. & Pakistan & $\begin{array}{l}\text { 2005-2014 } \\
\text { dönemi }\end{array}$ & $\begin{array}{l}\text { En küçük kareler } \\
\text { yöntemi ve panel veri }\end{array}$ & $\begin{array}{l}\text { - Kar payı dağıtım } \\
\text { - } \text { Karanı } \\
\text { - } \text { Firma büyüklüğü }\end{array}$ & $\begin{array}{l}\text { Karlılık, firma büyüklüğü ve finansal kaldıraç } \\
\text { ile kar payı dağıtım oranı arasında anlamlı ve } \\
\text { pozitif ilişkinin varlığı ortaya çıkarııırken, }\end{array}$ \\
\hline
\end{tabular}




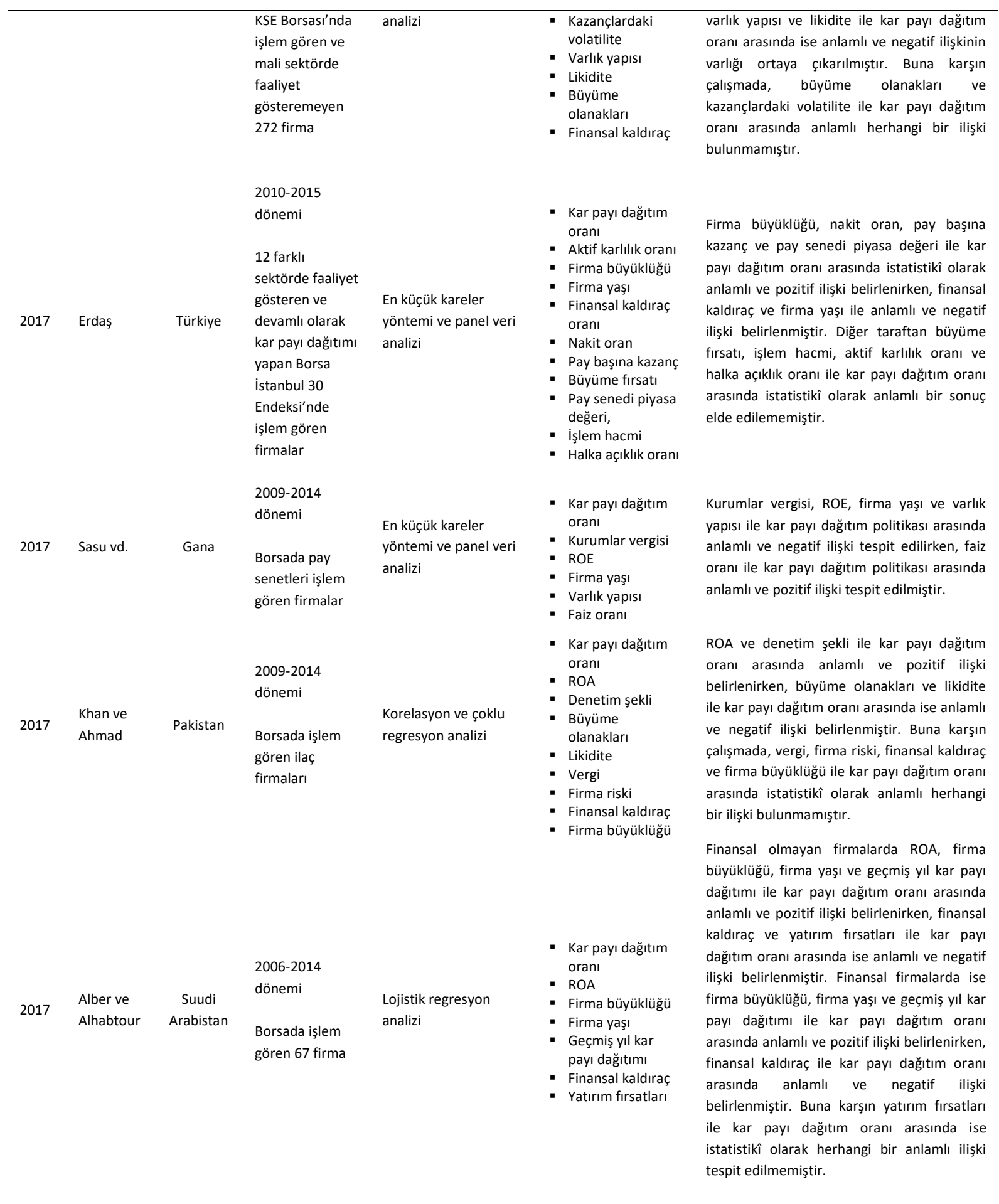




\section{VERI SETI, MODEL, YÖNTEM VE TAHMIN SONUÇLARI}

Çalışmanın bu kısmında, panel veri analiz yöntemi kullanılarak Borsa İstanbul (BIST) 100 Endeksi'nde payları devamlı olarak işlem gören, BIST 100 kapsamından incelenen dönem itibariyle çıkarılmamış olan ve verilerine tam olarak ulaşılabilen 33 firmanın nakit kar payı dağıtım politikalarına etki eden mikro ve makro faktörler belirlenmeye çalışılmıştır. BIST 100 Endeksi'nin Türkiye'nin en büyük firmalarını kapsaması ve bu firmaların diğer firmalara göre daha düzenli kar payı dağıtmaları, çalışmada bu endeksin tercih edilmesinin sebebidir. Bu doğrultuda firma verileri, 2010-2016 yılları itibariyle toplanarak analizde kullanılmıştır. Firmaların kar payı dağıtım politikalarına ve firmaya özgü mikro faktörlere ilişkin veriler, Borsa İstanbul (www.borsaistanbul.com) ve Kamuyu Aydınlatma Platformu (www.kap.org.tr) veri tabanlarından elde edilmiştir. Makroekonomik faktörlere ilişkin verilere ise Merkez Bankası (www.tcmb.gov.tr) veri tabanından ulaşılmıştır. Bu doğrultuda firma verileri yıllar itibariyle toplanarak, 7 yılı içeren panel veri seti oluşturulmuştur. Çalışmada incelenen firmalar Tablo 2'de gösterilmektedir.

Tablo 2: Çalışmaya Dâhil Edilen Firmalar

\begin{tabular}{|c|c|c|c|}
\hline $\begin{array}{l}\text { BIST } \\
\text { KODU }\end{array}$ & FIRMA & $\begin{array}{l}\text { BIST } \\
\text { KODU }\end{array}$ & FiRMA \\
\hline AEFES & ANADOLU EFES BIRACILIK & KARSN & KARSAN OTOMOTIV SAN TIC \\
\hline AFYON & AFYON CIMENTO & KARTN & KARTONSAN \\
\hline AKENR & AK ENERJI ELEKTRIK URETIM & KRDMD & KARDEMIR D GRUBU \\
\hline AKSA & AKSA AKRILIK & MGROS & MIGROS TICARET \\
\hline ARCLK & ARCELIK & NETAS & NORTEL NETWORKS NETAS TELEKOM \\
\hline ASELS & ASELSAN & NTTUR & NET TURIZM TIC VE SAN \\
\hline AYGAZ & AYGAZ & OTKAR & OTOKAR OTOMOTIV VE SAVUNMA SANAI \\
\hline BAGFS & BAGFAS & PETKM & PETKIM \\
\hline BFREN & BOSH FREN SISTEMLERI & PRKME & PARK ELEKTRIK URETIM MAD SAN \\
\hline BIMAS & BIM BIRLESIK MAGAZALAR & TCELL & TURKCELL ILETISIM HIZMETLERI \\
\hline DOAS & DOGUS OTOMOTIV & THYAO & TURK HAVA YOLLARI \\
\hline ENKAI & ENKA INSAAT VE BAYINDIRLIK & TOASO & TOFAS TURK OTOMOTIV FABRIKASI \\
\hline EREGL & EREGLI DEMIR CELIK & TRKCM & TRAKYA CAM \\
\hline FROTO & FORD OTOMOTIV SANAYI & TTKOM & TURK TELEKOMUNIKASYON \\
\hline GOLTS & GOLTAS GOLLER BOLGESI CIMENTO & TUPRS & TUPRS TURKIYE PETROL \\
\hline \multirow[t]{2}{*}{ GUBRF } & GUBRE FABRIKALARI & ULKER & ULKER BISKUVI SANAYI \\
\hline & & ZOREN & ZORLU ENERJI ELEK URET OTOPRD GR \\
\hline
\end{tabular}

Kaynak: www.borsaistanbul.com

Firmaların kar payı dağıtım politikalarına ilişkin teorik çerçeve ve literatürde yer alan, daha önceki çalışmalar dikkate alınarak, çalışmada kullanılan değişkenler belirlenmiş ve araştırma modeli oluşturulmuştur. Türkiye'de para politikalarının enflasyon ve faiz oranları esas alınarak belirlenmesi, çalışmada makro faktör olarak faiz oranı ve enflasyon oranının kullanılmasını açıklamaktadır. Diğer taraftan döviz kurlarındaki volatilitenin yüksek olması doğrultusunda döviz kuru, makro değişken olarak analize dâhil edilmemiştir. Bu bağlamda firmaların nakit kar payı dağıtım politikaları ile mikro ve makro faktörler arasındaki ilişki, panel veri analiz yöntemi ile incelenmiştir. Çalışmada kullanılan açıklayıcı değişkenlere yönelik formüller ve tanımlamalar Tablo 3'te sunulmaktadır.

Tablo 3: Modelde kullanılan Değişkenler ve Tanımlamalar

\begin{tabular}{lll}
\hline Açıklayıcı Değişken & Notasyon & Tanımlama \\
\hline Nakit Kar Payı Dağııı Oranı & NKPDO & Nakit Kar Payı Ödemeleri / Dönem Net Karı \\
Varlık Yapısı & VY & Maddi Duran Varlıklar / Toplam Varlıklar \\
$\begin{array}{l}\text { Aktif Karlılık Oranı } \\
\text { Likidite Oranı }\end{array}$ & ROA & Net Dönem Karı / Toplam Varlıklar \\
Finansal Kaldıraç & LKDT & (Dönen Varlıklar - Stoklar) / Kısa Vadeli Borçlar \\
Büyüme Fırsatı & FINK & (Kısa Vadeli Borçlar + Uzun Vadeli Borçlar) / Toplam Varlıklar \\
Firma Büyüklüğü & BUYF & (Dönem Sonu Satış Gelirleri / Dönem Başı Satış Gelirleri) - 1 \\
Piyasa Değeri & BUY & Toplam Varlıkların Logaritması \\
Altın & PD & Hisse Senedi Sayısı × Hisse Senedi Fiyatı \\
Enflasyon & ALT & 1 Ons Altın Londra Satış Fiyatı (ABD Doları/Ons) Altın Fiyatları \% Değişim \\
Faiz Oranı & (Ortalama)-Serbest Piyasa \\
\hline
\end{tabular}


Nakit kar payı dağıtım oranı ile kar payı dağıtım politikasına etki eden ve makro düzeydeki faktörler arasındaki ilişkiler ve bu ilişkiler sonrasında beklenen etkiler, ilintisizlik teorisi, eldeki kuş teorisi, vergi etkisi teorisi, müşteri etkisi teorisi, sinyal etkisi teorisi ve temsil maliyeti teorisi doğrultusunda Tablo 4'te gösterilmektedir.

Tablo 4: Nakit Kar Payı Dağıtım Politikası ile Mikro ve Makro Faktörler Arasındaki ilişkinin Kar Payı Dağıtım Teorileri Doğrultusunda Öngörüleri

\begin{tabular}{lcccccc}
\hline Değişkenler & $\begin{array}{c}\text { İlintisizlik } \\
\text { Teorisi }\end{array}$ & $\begin{array}{c}\text { Eldeki Kuş } \\
\text { Teorisi }\end{array}$ & $\begin{array}{c}\text { Vergi Etkisi } \\
\text { Teorisi }\end{array}$ & $\begin{array}{c}\text { Müşteri } \\
\text { Etkisi Teorisi }\end{array}$ & $\begin{array}{c}\text { Sinyal } \\
\text { Teorisi }\end{array}$ & $\begin{array}{c}\text { Temsil Maliyeti } \\
\text { Teorisi }\end{array}$ \\
\hline Varlık Yapısı & $+/-$ & + & + & $+/-$ & - & - \\
Aktif Karlılık & $+/-$ & - & - & $+/-$ & + & + \\
Likidite Oranı & $+/-$ & - & - & $+/-$ & + & + \\
Finansal Kaldıraç & $+/-$ & + & + & $+/-$ & - & - \\
Büyüme Fırsatı & + - & + & + & $+/-$ & - & - \\
Büyüklük & $+/-$ & - & + & $+/-$ & - & - \\
Piyasa Değeri & Yok & + & + & $+/-$ & - & - \\
Altın & $+/-$ & + & + & +- & + & + \\
Enflasyon & $+/-$ & + & + & $+/-$ & + & + \\
Faiz & $+/-$ & + & + & + & + \\
\hline
\end{tabular}

Kaynak: Konuya ilişkin teorik altyapı ve literatürde yer alan çalışmalardan elde edilen bulgular doğrultusunda yazarlar tarafından oluşturulmuştur.

Kar payı dağıtım politikasına etki eden mikro ve makro faktörler ile firmaların piyasa değerleri arasındaki ilişkileri açıklamaya çalışan teoriler doğrultusunda öngörülen ilişkinin yönü, değişken bazında farklılaşabilmektedir. Çalışmada mikro ve makro faktörler ayrı ayrı ele alınarak firmaların nakit kar payı dağıtım politikalarına olan etkileri teorik olarak ilişkilendirilmeye çalışılmıştır. Kar payı dağıtım teorileri doğrultusunda çalışmada kullanılan bağımlı ve bağımsız değişkenler arasındaki ilişkinin test edilmesi için oluşturulan hipotezler ise Tablo 5 'te yer almaktadır.

Tablo 5: Çalışmada Test Edilen Hipotezler

\begin{tabular}{|c|c|c|}
\hline Mikro Faktörler & $\mathrm{H}_{1}$ & $\begin{array}{l}\text { Nakit kar payı dağıtım oranı ile mikro değişkenlerden en az birisi arasında pozitif/negatif yönlü } \\
\text { doğrusal ilişki vardır. }\end{array}$ \\
\hline Makro Faktörler & $\mathrm{H}_{2}$ & $\begin{array}{l}\text { Nakit kar payı dağıtım oranı ile makro değişkenlerden en az birisi arasında pozitif/negatif } \\
\text { yönlü doğrusal ilişki vardır. }\end{array}$ \\
\hline \multirow{2}{*}{ Varlık Yapısı } & $\mathrm{H}_{3}$ & Nakit kar payı dağıtım oranı ile varlık yapısı arasında pozitif yönlü doğrusal ilişki vardır. \\
\hline & $\mathrm{H}_{4}$ & Nakit kar payı dağıtım oranı ile varlık yapısı arasında negatif yönlü doğrusal ilişki vardır. \\
\hline \multirow{2}{*}{ Aktif Karlılık } & $\mathrm{H}_{5}$ & Nakit kar payı dağıtım oranı ile aktif karlıık oranı arasında pozitif yönlü doğrusal ilişki vardır. \\
\hline & $\mathrm{H}_{6}$ & Nakit kar payı dağıtım oranı ile aktif karlılık oranı arasında negatif yönlü doğrusal ilişki vardır. \\
\hline \multirow{2}{*}{ Likidite Oranı } & $\mathrm{H}_{7}$ & Nakit kar payı dağıtım oranı ile likidite oranı arasında pozitif yönlü doğrusal ilişki vardır. \\
\hline & $\mathrm{H}_{8}$ & Nakit kar payı dağıtım oranı ile likidite oranı arasında negatif yönlü doğrusal ilişki vardır. \\
\hline \multirow{2}{*}{ Finansal Kaldıraç } & $\mathrm{H}_{9}$ & Nakit kar payı dağıtım oranı ile finansal kaldıraç arasında pozitif yönlü doğrusal ilişki vardır. \\
\hline & $\mathrm{H}_{10}$ & Nakit kar payı dağıtım oranı ile finansal kaldıraç arasında negatif yönlü doğrusal ilişki vardır. \\
\hline \multirow{2}{*}{ Büyüme Fırsatı } & $\mathrm{H}_{11}$ & Nakit kar payı dağıtım oranı ile büyüme fırsatı arasında pozitif yönlü doğrusal ilişki vardır. \\
\hline & $\mathrm{H}_{12}$ & Nakit kar payı dağıtım oranı ile büyüme fırsatı arasında negatif yönlü doğrusal ilişki vardır. \\
\hline \multirow{2}{*}{ Büyüklük } & $\mathrm{H}_{13}$ & Nakit kar payı dağıtım oranı ile büyüklük arasında pozitif yönlü doğrusal ilişki vardır. \\
\hline & $\mathrm{H}_{14}$ & Nakit kar payı dağıtım oranı ile büyüklük arasında negatif yönlü doğrusal ilişki vardır. \\
\hline \multirow{2}{*}{ Piyasa Değeri } & $\mathrm{H}_{15}$ & Nakit kar payı dağıtım oranı ile piyasa değeri arasında pozitif yönlü doğrusal ilişki vardır. \\
\hline & $\mathrm{H}_{16}$ & Nakit kar payı dağıtım oranı ile piyasa değeri arasında negatif yönlü doğrusal ilişki vardır. \\
\hline \multirow{2}{*}{ Altın } & $\mathrm{H}_{17}$ & Nakit kar payı dağıtım oranı ile altın fiyatı arasında pozitif yönlü doğrusal ilişki vardır. \\
\hline & $\mathrm{H}_{18}$ & Nakit kar payı dağıtım oranı ile altın fiyatı arasında negatif yönlü doğrusal ilişki vardır. \\
\hline \multirow{2}{*}{ Enflasyon } & $\mathrm{H}_{19}$ & Nakit kar payı dağıtım oranı ile enflasyon arasında pozitif yönlü doğrusal ilişki vardır. \\
\hline & $\mathrm{H}_{20}$ & Nakit kar payı dağıtım oranı ile enflasyon arasında negatif yönlü doğrusal ilişki vardır. \\
\hline \multirow{2}{*}{ Faiz } & $\mathrm{H}_{21}$ & Nakit kar payı dağıtım oranı ile faiz oranı arasında pozitif yönlü doğrusal ilişki vardır. \\
\hline & $\mathrm{H}_{22}$ & Nakit kar payı dağıtım oranı ile faiz oranı arasında negatif yönlü doğrusal ilişki vardır. \\
\hline
\end{tabular}


Çalışmada kullanılan veri setinin, yatay kesit verileri ile zaman serilerini bir araya getirmesi ve dolayısıla panel veri analizine uygun formatta olması, firmaların kar payı dağıtım politikalarına etki eden faktörlerin panel veri analizi ile tespit edilebilmesine imkân tanımaktadır. Bu bağlamda oluşturulan ekonometrik model aşağıdaki gibi formüle edilmiştir.

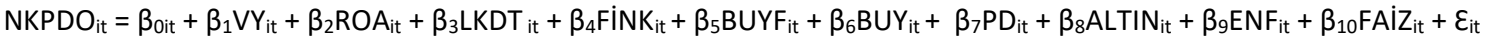

Denklemde, $i=1,2,3, \ldots . . . N$ yatay kesit birimlerini ifade ederken, $t=1,2,3, \ldots \ldots .$. T zaman boyutunu, $\varepsilon$ ise panel hata terimini ifade etmektedir.

Panel veri analizi kapsamında öncelikle bağımsız değişkenler arasında çoklu doğrusal bağlantı sorununun olup olmadığına yönelik olarak spearman korelasyon analizi ve varyans şişirme testi gerçekleştirilmiştir. Çoklu doğrusal bağlantı sorununa yol açabilecek kritik değerlerin üzerinde değer alan değişkenler analizden çıkarılmıştır. Analizde kullanılacak değişkenlerin belirlenmesi sonrasında serilerin durağanlıkları incelenmektedir. Zaman serilerinin durağanlıkları, Im-Peseran-Shin W istatistiği, Fisher-ADF ve Levin, Lin ve Chu t testleri ile sınanmıştır. Serilerin durağanlıkları sağlandıktan sonra, Breusch-Pagan ve Peseran CD testleri ile yatay kesit bağımlılı̆ı, Breusch-Godfrey testi ile otokorelasyon, White testi ile değişen varyans problemlerinin olup olmadığı araştırılmıştır. Model tahmini için sabit etkiler, rassal etkiler veya havuzlanmış tahmin modellerinden hangisinin kullanılacağına ise $\mathrm{F}$ testi ve Breusch-Pagan LM testi ile karar verilmiştir. Tahmin modeline karar verilmesinin ardından, oluşturulan modelde yatay kesit bağımlılığı, otokorelasyon ya da değişen varyans sorunlarının varlığı incelenmiştir. Modelin tahmin edilme aşamasında değişen varyans ve/veya otokorelasyon sorunlarından birinin bulunması halinde, genelleştirilmiş en küçük kareler yönteminin (EGLS) veya Uygulanabilir Genelleştirilmiş En Küçük Kareler (FGSL) yönteminin kullanılmasının daha uygun olduğu öngörülmektedir. Çalışmada bu sorunları ortadan kaldıran White standart hataların düzeltilmesi yöntemi ile tahminleme yapılmıştır. Bu yöntem, yatay kesitler arasındaki farklı hata varyanslarının yanı sıra korelasyon sorununa da çözüm sunmaktadır (Korkmaz vd., 2010: 102).

\section{BULGULAR}

Yukarıda yönteme dair yapılan açıklamalar doğrultusunda, panel veri analizine geçmeden önce bağımsız değişkenler arasında çoklu doğrusal bağlantı probleminin olup olmadığını belirleyebilmek için, en az bir değişkenin normal dağılıma sahip olmadığı varsayımı altında kullanılan, Spearman korelasyon analizi ve varyans şişirme faktör testi gerçekleştirilmiştir. Analiz sonuçları Tablo 6'da ve Tablo 7'de gösterilmektedir.

Tablo 6: Spearman Korelasyon Analiz Sonuçları

\begin{tabular}{|c|c|c|c|c|c|c|c|c|c|c|}
\hline $\begin{array}{l}\text { Korelasyon } \\
\text { t-İstatisik } \\
\text { Olasılık }\end{array}$ & VY & ROA & LKDT & FINK & BUYF & BUY & ALTIN & ENF & FAIZ & PD \\
\hline \multirow{2}{*}{ VY } & ----- & & & & & & & & & \\
\hline & ----- & & & & & & & & & \\
\hline ROA & -0.299049 & 1.000000 & & & & & & & & \\
\hline \multirow[t]{3}{*}{ LKDT } & -0.262183 & 0.213328 & 1.000000 & & & & & & & \\
\hline & -4.111370 & 3.304297 & ----- & & & & & & & \\
\hline & 0.0001 & 0.0011 & ----- & & & & & & & \\
\hline \multirow[t]{2}{*}{ FINK } & 0.092873 & -0.365753 & -0.642217 & 1.000000 & & & & & & \\
\hline & 1.411520 & -5.946893 & -12.67868 & ----- & & & & & & \\
\hline BUYF & 0.4755 & 0.0224 & 0.2971 & 0.3152 & ----- & & & & & \\
\hline \multirow[t]{3}{*}{ BUY } & 0.068581 & -0.020714 & -0.129221 & 0.332180 & -0.056273 & 1.000000 & & & & \\
\hline & 1.040275 & -0.313527 & -1.972007 & 5.329429 & -0.852909 & ----- & & & & \\
\hline & 0.2993 & 0.7542 & 0.0498 & 0.0000 & 0.3946 & ----- & & & & \\
\hline \multirow[t]{3}{*}{ ALTIN } & -0.056739 & 0.125034 & 0.015288 & -0.067256 & 0.059433 & -0.093175 & 1.000000 & & & \\
\hline & -0.860003 & 1.907069 & 0.231382 & -1.020076 & 0.900980 & -1.416151 & ----- & & & \\
\hline & 0.3907 & 0.0578 & 0.8172 & 0.3088 & 0.3685 & 0.1581 & ----- & & & \\
\hline ENF & -0.008797 & -0.183785 & -0.097119 & 0.150774 & -0.183526 & 0.231225 & -0.357143 & 1.000000 & & \\
\hline
\end{tabular}




\begin{tabular}{lrrrrrrrrrr} 
FAIZ & 0.029895 & -0.167263 & -0.066964 & 0.116659 & -0.190082 & 0.174421 & -0.714286 & 0.750000 & 1.000000 & \\
& 0.452598 & -2.567322 & -1.015626 & 1.777510 & -2.929885 & 2.680554 & -15.44479 & 17.15892 & ---- & \\
\multirow{3}{*}{ PD } & 0.6513 & 0.0109 & 0.3109 & 0.0768 & 0.0037 & 0.0079 & 0.0000 & 0.0000 & ----- & \\
& -0.042718 & 0.202395 & -0.025242 & 0.197119 & -0.057184 & 0.872094 & -0.072660 & 0.159149 & 0.146879 & 1.000000 \\
& -0.647031 & 3.127520 & -0.382102 & 3.042657 & -0.866766 & 26.96941 & -1.102466 & 2.439448 & 2.247053 & ---- \\
& 0.5183 & 0.0020 & 0.7027 & 0.0026 & 0.3870 & 0.0000 & 0.2714 & 0.0155 & 0.0256 & ---- \\
\hline
\end{tabular}

Not: Tabloda; Nakit Kar Payı Dağııım Oranı (NKPDO), Varlık Yapısı (VY), Aktif Karlııık Oranı (ROA), Likidite Oranı (LKDT), Finansal Kaldıraç (FINK), Büyüme Fırsatı (BUYF), Büyüklük (BUY), Piyasa Değeri (PD), Altın Fiyatı (ALTIN), Enflasyon Oranı (ENF), Faiz Oranı (FAIZ) ile gösterilmektedir.

Tablo 6'da bağımsız değişkenler arasında tam ilişki olmaması gerekliliğine işaret eden çoklu doğrusal bağlantı varsayımını test etmek için bağımsız değişkenler arasındaki korelasyon katsayıları incelenmiştir. Değişkenler arasındaki korelasyon katsayısının 0.90'ın üzerinde olması sorun yaratmaktadır (Tabachnick ve Fidell, 2001). Çalışmada kullanılan değişkenler arasında en yüksek korelasyon katsayısı 0.87 olarak hesaplanmıştır. Çoklu doğrusal bağlantı sorununu belirleyebilmek amacıyla kullanılan bir diğer ölçüt ise Varyans Şişirme Faktörü (VIF) değerleridir. VIF değerinin 10'dan küçük olması, değişkenler arasında çoklu doğrusal bağlantı sorununun olmadığına işaret etmektedir (Hair, vd. 1998).

Tablo 7: Varyans Şişirme Faktör (VIF) Değerleri

\begin{tabular}{lcc}
\hline Değişken & Varyans Katsayısı & Merkezi VIF \\
\hline VY & 0.063731 & 1.214828 \\
ROA & 0.498028 & 1.447568 \\
LKDT & 0.001775 & 1.737824 \\
FINK & 0.075442 & 1.935043 \\
BUYF & 0.030846 & 1.073939 \\
BUY & 0.002705 & 3.452755 \\
PD & 0.002762 & 3.275996 \\
ALTIN & 0.396969 & 3.392018 \\
ENF & 0.394260 & 3.673601 \\
FAIZ & 0.002489 & 7.479156 \\
C & 17.30553 & NA \\
\hline Not: Tabloda; Varlık Yapısı (VY), Aktif Karlılık Oranı (ROA), Likidite \\
Oranı (LKDT), Finansal Kaldıraç (FINK), Büyüme Fırsatı (BUYF), \\
Büyüklük (BUY), Piyasa Değeri (PD), Altın Fiyatı (ALTIN), Enflasyon \\
Oranı (ENF) ve Faiz Oranı (FAIZ) ile gösterilmektedir. \\
\hline
\end{tabular}

Tablo 7'de yer alan VIF değerleri incelendiğinde, çalışmada kullanılan bağımsız değişkenlerin VIF değerleri 1.07 ile 7.47 arasında değer aldıkları tespit edilmiştir. Dolayısıyla bağımsız değişkenler arasında çoklu doğrusal bağlantı probleminin olmadığı söylenebilir. Bu bulgular, korelasyon analizinden elde edilen sonuçları destekler niteliktedir.

Nakit kar payı dağıtım politikasına etki eden mikro ve makro faktörlere ilişkin tanımlayıcı istatistikî bilgiler Tablo 8'de verilmektedir. 
Tablo 8: Tanımlayıcı İstatistikler

\begin{tabular}{|c|c|c|c|c|c|c|c|c|c|c|c|}
\hline & NKPDO & VY & ROA & LKDT & FINK & BUYF & BUY & PD & ALTIN & ENF & FAIZ \\
\hline Ortalama & 0.462 & 0.349 & 0.061 & 1.462 & 0.524 & 0.162 & 21.74 & 21.51 & 7.209 & 5.372 & 6.454 \\
\hline Medyan & 0.273 & 0.318 & 0.064 & 1.077 & 0.557 & 0.127 & 21.88 & 21.39 & 7.143 & 5.361 & 5.804 \\
\hline Maksimum & 4.975 & 0.876 & 0.435 & 10.99 & 1.038 & 1.863 & 24.89 & 24.17 & 7.420 & 5.546 & 9.452 \\
\hline Minimum & 0.000 & 0.029 & -0.151 & 0.112 & 0.075 & -0.607 & 17.67 & 14.17 & 7.054 & 5.152 & 2.998 \\
\hline Std.S ap. & 0.662 & 0.188 & 0.073 & 1.350 & 0.218 & 0.254 & 1.542 & 1.487 & 0.126 & 0.131 & 2.367 \\
\hline Çarpıklık & 3.040 & 0.521 & 0.339 & 3.329 & -0.152 & 1.892 & -0.551 & -0.386 & 0.503 & -0.225 & 0.020 \\
\hline Basıklık & 15.96 & 2.376 & 5.786 & 18.20 & 2.283 & 12.72 & 2.938 & 4.022 & 1.787 & 1.826 & 1.476 \\
\hline
\end{tabular}

Tablo 8'de Türkiye'nin en büyük firmaları konumunda olan ve Borsa İstanbul 100 Endeksi'nde payları devamlı olarak işlem gören firmaların nakit kar payı dağıım politikalarına etki eden çeşitli faktörlere ilişkin tanımlayıcı istatistikler sunulmaktadır. Endekste yer alan firmaların ortalama 0.462 oranında nakit kar payı dağıttıklarını söylemek mümkündür. Analize dâhil edilen firmaların büyük ölçekli firmalar olması ve karlılıkları doğrultusunda devamlı olarak kar payı dağıttıkları dikkate alındığında, bu oranın normal seviyede olduğu ifade edilebilir. Diğer değişkenlere ilişkin ortalama değerler incelendiğinde; varlık yapısının 0.349, aktif karlıık oranının 0.061, likidite oranının 1.462, finansal kaldıraç oranının 0.524, büyüme fırsatının 0.162, firma büyüklüğünün 21.74, altın fiyatının 7.209, enflasyon oranının 5.372, faiz oranının 6.454 ve piyasa değerinin 21.51 olduğu görülmüştür. Tanımlayıcı istatistikî bilgiler genel olarak analiz edildiğinde, firmaların aktif karlılıklarının pozitif olduğu, sermaye yapılarının yarıdan fazlasını yabancı kaynakla finanse edildiği, aktif büyüklüklerinin ve likidite durumlarının yeterli, piyasa değerlerinin ise pozitif olduğu görülmektedir.

Panel veri analizini gerçekleştirebilmek ve doğru sonuçlar elde edebilmek için değişkenlere ilişkin zaman serilerinin durağanlığının sağlanması gerekmektedir (Gujarati, 2003). Bu bağlamda çalışmada, zaman serilerinin sabitli ve sabitli/trendli modeller kapsamında durağanlıkları, Levin, Lin ve Chu t, Im-Peseran-Shin W istatistiği ve Fisher-ADF testleri ile sınanmıştır. Birim kök analiz sonuçları Tablo 9'da gösterilmektedir.

Tablo 9: Panel Birim Kök Testi İstatistik Sonuçları

\begin{tabular}{|c|c|c|c|c|c|c|c|c|c|c|c|c|}
\hline \multicolumn{13}{|c|}{ Sabitli Terim } \\
\hline \multirow{3}{*}{ Değişken } & \multicolumn{4}{|c|}{ LLC } & \multicolumn{4}{|c|}{ IPS } & \multicolumn{4}{|c|}{ Fisher-ADF } \\
\hline & \multicolumn{2}{|c|}{ Düzey I(0) } & \multicolumn{2}{|c|}{ Düzey I(1) } & \multicolumn{2}{|c|}{ Düzey I(0) } & \multicolumn{2}{|c|}{ Düzey I(1) } & \multicolumn{2}{|c|}{ Düzey I(0) } & \multicolumn{2}{|c|}{ Düzey I(1) } \\
\hline & T-ìst. & Prob. & T-ìst. & Prob. & T-ìst. & Prob. & T-ìst. & Prob. & T-i̇st. & Prob. & T-i̇st. & Prob. \\
\hline NKPDO & -9.821 & $0.000^{* * *}$ & & & -2.529 & $0.005^{* * *}$ & & & 94.41 & $0.001^{* * *}$ & & \\
\hline VY & -15.16 & $0.000^{* * *}$ & & & -1.985 & $0.023^{* *}$ & & & 91.32 & $0.021^{* *}$ & & \\
\hline ROA & -7.853 & $0.000^{* * *}$ & & & -1.579 & $0.057^{*}$ & & & 89.64 & $0.028^{* *}$ & & \\
\hline LKDT & -7.201 & $0.000^{* * *}$ & & & -0.685 & 0.246 & -3.142 & $0.000^{* * *}$ & 79.25 & 0.126 & 116.5 & $0.000^{* * *}$ \\
\hline FINK & -7.789 & $0.000^{* * *}$ & & & -0.020 & 0.491 & -4.295 & $0.000^{* * *}$ & 77.24 & 0.162 & 135.1 & $0.000^{* * *}$ \\
\hline BUYF & -12.06 & $0.000^{* * *}$ & & & -3.425 & $0.000^{* * *}$ & & & 20.90 & $0.000^{* * *}$ & & \\
\hline BUY & 1.437 & 0.924 & -12.22 & $0.000^{* * *}$ & 4.972 & 1.000 & -3.517 & $0.000^{* * *}$ & 29.36 & 1.000 & 124.8 & $0.000^{* * *}$ \\
\hline PD & -18.05 & $0.000^{* * *}$ & & & -2.231 & $0.012^{* *}$ & & & 86.18 & $0.048^{* *}$ & & \\
\hline ALTIN & -1.015 & 0.155 & -9.723 & $0.000^{* * *}$ & 0.723 & 0.765 & -2.215 & $0.013^{* *}$ & 41.93 & 0.990 & 97.61 & $0.006^{* * *}$ \\
\hline ENF & -12.01 & $0.000^{* * *}$ & & & -0.694 & 0.243 & -3.316 & $0.000^{* * *}$ & 65.23 & 0.503 & 119.6 & $0.000^{* * *}$ \\
\hline FAIZ & 1.743 & 0.959 & -26.03 & $0.000^{* * *}$ & 3.475 & 0.999 & -9.058 & $0.000^{* * *}$ & 15.45 & 1.000 & 223.2 & $0.000^{* * *}$ \\
\hline
\end{tabular}




\begin{tabular}{|c|c|c|c|c|c|c|c|c|c|c|c|c|}
\hline \multicolumn{13}{|c|}{ Sabitli /Trendli Terim } \\
\hline \multirow{3}{*}{ Değişken } & \multicolumn{4}{|c|}{ LLC } & \multicolumn{4}{|c|}{ IPS } & \multicolumn{4}{|c|}{ Fisher-ADF } \\
\hline & \multicolumn{2}{|c|}{ Düzey I(0) } & \multicolumn{2}{|c|}{ Düzey I(1) } & \multicolumn{2}{|c|}{ Düzey I(0) } & \multicolumn{2}{|c|}{ Düzey I(1) } & \multicolumn{2}{|c|}{ Düzey I(0) } & \multicolumn{2}{|c|}{ Düzey I(1) } \\
\hline & T-isst. & Prob. & T-isst. & Prob. & T-isst. & Prob. & T-ìst. & Prob. & T-íst. & Prob. & T-ìst. & Prob. \\
\hline NKPDO & -8.449 & $0.000^{* * *}$ & & & -0.784 & 0.216 & -1.153 & 0.124 & 82.58 & $0.028^{* *}$ & & \\
\hline VY & -15.59 & $0.000^{* * *}$ & & & -3.056 & $0.001^{* * *}$ & & & 137.8 & $0.000^{* * *}$ & & \\
\hline ROA & -13.62 & $0.000^{* * *}$ & & & -0.721 & 0.235 & -2.724 & $0.003^{* * *}$ & 90.43 & $0.024^{* *}$ & & \\
\hline LKDT & -8.004 & $0.000^{* * *}$ & & & 0.535 & 0.703 & -3.484 & $0.000^{* * *}$ & 59.08 & 0.714 & 104.2 & $0.001^{* * *}$ \\
\hline FINK & -12.63 & $0.000^{* * *}$ & & & 0.251 & 0.599 & -1.743 & $0.040^{* *}$ & 69.51 & 0.359 & 114.8 & $0.000^{* * *}$ \\
\hline BUYF & -19.36 & $0.000^{* * *}$ & & & -1.245 & 0.106 & -2.931 & $0.001^{* * *}$ & 104.64 & $0.001^{* * *}$ & & \\
\hline BUY & -7.328 & $0.000^{* * *}$ & & & 0.744 & 0.771 & -0.894 & 0.185 & 57.66 & 0.757 & 93.91 & $0.013^{* *}$ \\
\hline PD & -25.62 & $0.000^{* * *}$ & & & -1.690 & $0.045^{* *}$ & & & 114.4 & $0.000^{* * *}$ & & \\
\hline ALTIN & -17.04 & $0.000^{* * *}$ & & & -1.202 & 0.114 & 3.132 & 0.999 & 101.41 & $0.003^{* * *}$ & & \\
\hline ENF & -14.08 & $0.000^{* * *}$ & & & -0.102 & 0.459 & 0.315 & 0.623 & 72.17 & 0.281 & 60.10 & 0.681 \\
\hline FAIZ & -21.40 & $0.000^{* * *}$ & & & -2.381 & $0.008^{* * *}$ & & & 143.9 & $0.000^{* * *}$ & & \\
\hline
\end{tabular}

Tablo 9'dan da görüleceği üzere, tüm serilerin sabitli ve sabitli/trendli terimde en az bir testte farklı anlamlılık düzeylerinde durağan oldukları belirlenmiştir. Düzeyde durağan olmayan değişkenler için fark alma işlemi uygulanarak tüm seriler için durağanlık sağlanmıştır. Dolayısıyla değişkenlere ilişkin zaman serilerinin analiz için uygun olduğu belirlenmiştir.

Birim kök analizi sonrasında panel veri analizini gerçekleştirebilmek için gerekli diğer varsayımlar ise serilerde yatay kesit bağımlılı̆ı, otokorelasyon ve değişen varyans sorunlarının olup olmadı̆̆ıdır. Çalışmada, yatay kesit ve zaman boyutu doğrultusunda yatay kesit bağımlılığı Pesaran CD testi ile araştırılırken, otokorelasyon ve değişen varyans ise Breusch-Godfrey LM ve White testleri ile araştırılmıştır. Diagnostik testlere ilişkin analizler sonrasında, tahminleme için hangi model tahmin yönteminin kullanılacağına dair Breusch-Pagan LM, Hausman ve F testleri gerçekleştirilmiştir. Analiz sonuçları Tablo 10'da yer almaktadır.

Tablo 10: Diagnostik ve Tahmin Modeli Seçim Test Sonuçları

\begin{tabular}{|c|c|c|c|}
\hline \multicolumn{4}{|c|}{ Diagnostik Test Sonuçları } \\
\hline Test & & İstatistik & Prob. \\
\hline \multirow{2}{*}{$\begin{array}{l}\text { Pesaran scaled LM } \\
\text { Pesaran CD }\end{array}$} & \multirow{2}{*}{ Yatay Kesit Bağımlılığı } & 1.463047 & 0.1435 \\
\hline & & -0.112133 & 0.9107 \\
\hline Breusch-Godfrey LM & \multirow{2}{*}{ Otokorelasyon } & Prob. $F(1,218)$ & 0.0388 \\
\hline \multirow[t]{2}{*}{ Testi } & & Prob. Chi-Square(1) & 0.0345 \\
\hline & & Prob. $F(62,167)$ & 0.8366 \\
\hline \multirow[t]{2}{*}{ White Testi } & Değişen Varyans & Prob. Chi-Square(62) & 0.7880 \\
\hline & & Prob. Chi-Square(62) & 0.0000 \\
\hline \multicolumn{4}{|c|}{ Tahmin Modeli Seçim Test Sonuçları } \\
\hline \multicolumn{4}{|c|}{ Breusch-Pagan LM Testi } \\
\hline \multicolumn{2}{|r|}{ Cross-section } & 8.445225 & 0.0037 \\
\hline \multicolumn{2}{|r|}{ Test Hypothesis Time } & 1.124228 & 0.2890 \\
\hline \multicolumn{2}{|r|}{ Both } & 9.569453 & 0.0020 \\
\hline \multicolumn{4}{|c|}{ Hausman Testi } \\
\hline \multicolumn{4}{|c|}{ Chi-Sq. Statistic } \\
\hline \multicolumn{2}{|r|}{ Chi-Sq. d.f. } & \multicolumn{2}{|c|}{10} \\
\hline & Prob & \multicolumn{2}{|c|}{1.0000} \\
\hline \multicolumn{4}{|c|}{ * Cross-section test variance is invalid. Hausman statistic set to zero. } \\
\hline \multicolumn{4}{|c|}{ F Testi } \\
\hline \multirow{3}{*}{ Cross-section $\mathrm{F}$} & Statistic & \multirow{2}{*}{\multicolumn{2}{|c|}{2.035524}} \\
\hline & d.f. & & $(32,155)$ \\
\hline & Prob. & \multicolumn{2}{|c|}{0.0023} \\
\hline Cross-section & Statistic & \multicolumn{2}{|c|}{69.463122} \\
\hline
\end{tabular}


Chi-square d.f. Prob.

Tablo 10'daki Diagnostik test sonuçları incelendiğinde, Pesaran CD test istatistiğinin kritik değer olan 0.05 'ten büyük olduğu ve modelde yatay kesit bağımlılığının olmadığı belirlenmiştir. Breusch-Godfrey LM otokorelasyon ve White değişen varyans test istatistik değerinin ise kritik değerden düşük olduğu tespit edilmiştir. Dolayısıyla modelde otokorelasyon ve değişen varyans sorunlarının varlığı belirlenmiştir. Tahmin modelinin belirlenmesi için gerçekleştirilen analiz sonuçları değerlendirildiğinde, tahmin modeli olarak havuzlanmış model/rassal etkiler modellerinden hangisinin tercih edileceği Breusch-Pagan LM testi ile sınanırken, sabit etkiler modeline karşı rassal etkiler modelinin tercih edilip edilmeyeceği ise Hausman testi ile sınanmıştır. Havuzlanmış/sabit etkiler modellerinden hangisinin tercih edilmesi gerektiğine ise $\mathrm{F}$ testi kullanılarak karar verilmiştir. $\mathrm{F}$ testinde zaman ve/veya yatay kesit etkilerinin olup olmadığı diğer bir deyişle tek ya da çift yönlü sabit etkiler modelinin geçerliliği incelenebilmektedir. Ancak çalışmanın zaman boyutunun dar olması, sabit etkiler modelinde yalnızca yatay kesit etkisinin incelenebilmesine imkân tanırken, zaman etkisinin varlığı test edilememektedir. Herhangi bir çalışmada kullanılan veriler, belirli spesifik bir gruptan ve belirli bir dönem esas alınarak oluşturulmuş ise modellerin nihai tahminlemesinde sabit etkiler modelinin kullanılması gerekmektedir (Baltagi, 2005: 12). Bu bağlamda testlerde elde edilen bulgular ve çalışmanın kapsamı doğrultusunda, modelin anlamlılı̆ı araştırılmış ve sabit etkiler modeli esas alınarak tahmin yapılmasına karar verilmiştir.

Panel FGLS doğrultusunda otokorelasyon ve değişen varyans sorunları, White'ın standart hataların düzeltilmesi yöntemi kullanılarak giderilmeye çalışılmıştır. Bu metod, yatay kesitler arasındaki farklı hata varyanslarının yanı sıra korelasyon sorununa da çözüm üretmektedir. Ulaşılan sonuçlar, Tablo 11'de gösterilmektedir.

Tablo 11: Panel Veri Analiz Sonuçları

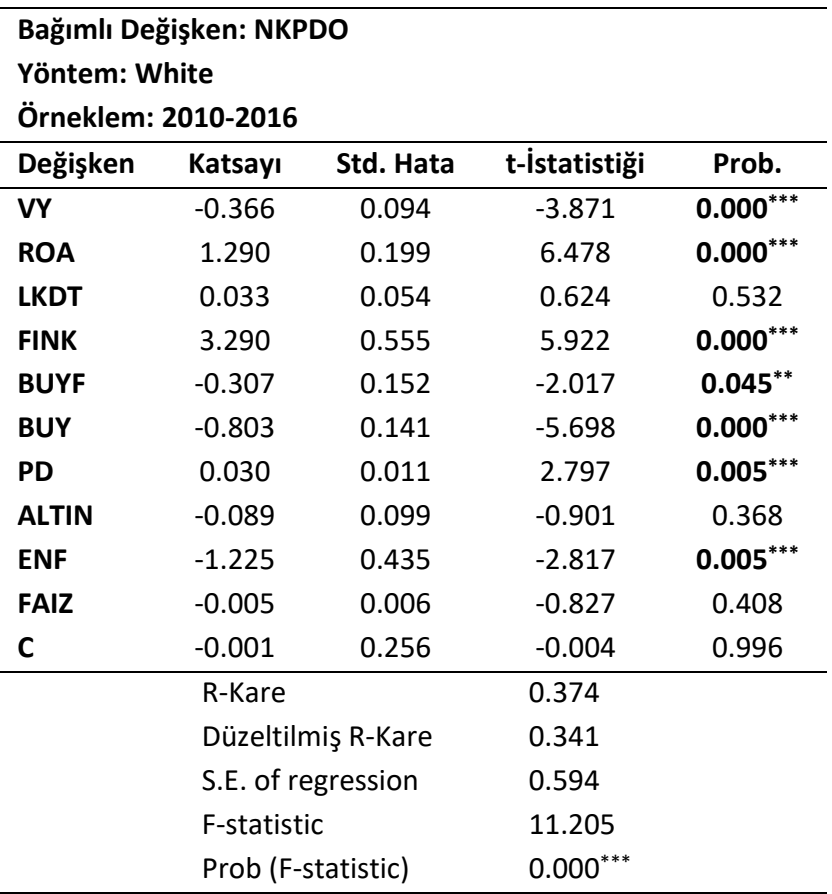

Not 1: ${ }^{* * *},{ }^{* *}$, ve ${ }^{*}$ simgeleri katsayıların sırasıyla \%1, \%5 ve \%10 önem düzeylerinde anlamlı olduğunu göstermektedir.

Not 2: Tabloda; Nakit Kar Payı Dağıtım Oranı (NKPDO), Varlık Yapısı (VY), Aktif Karlılık Oranı (ROA), Likidite Oranı (LKDT), Finansal Kaldıraç (FINK), Büyüme Fırsatı (BUYF), Büyüklük (BUY), Piyasa Değeri (PD), Altın Fiyatı (ALTIN), Enflasyon Oranı (ENF), Faiz Oranı (FAIZ) ile gösterilmektedir. 
Nakit kar payı dağıtım politikasına etki eden mikro ve makro faktörlerin araştırıldığı çalışmada, havuzlanmış model doğrultusunda elde edilen panel veri analiz sonuçları Tablo 10 'da gösterilmektedir. Modelin bir bütün olarak anlamlılı̆ını ifade eden F istatistiği olasılık değeri \%99 güven aralığında anlamlıdır. Analiz kapsamında incelenen bağımsız değişkenler, nakit kar payı dağıtım politikasında meydana gelen değişimin \%34'ünü açıklamaktadır.

Modelde yer alan açıklayıcı değişkenlerin olasılık değerleri incelendiğinde, varlık yapısı, aktif karlılık oranı, finansal kaldıraç oranı, firma büyüklüğü, enflasyon oranı ve piyasa değeri değişkenlerinin \%1, büyüme fırsatı değişkeninin ise \%5 anlamlılık düzeyinde istatistikî olarak anlamlı olduğu tespit edilmiştir. Buna karşın likidite oranı, altın fiyatı ve faiz oranı değişkenlerinin istatistikî olarak anlamlı olmadığı da belirlenmiştir.

\section{SONUÇ DEĞERLENDIRME VE ÖNERILER}

Bu çalışmada, payları Borsa İstanbul'da işlem gören ve BiST 100 Endeksine dâhil olan firmaların nakit kar payı dağıtım politikalarına etki eden mikro ve makro faktörlerin belirlenmesi amaçlanmıştır. Firmaların nakit kar payı dağıtım politikası, nakit kar payı dağıtım oranı ile temsil edilirken, kar payı dağıtım politikasını etkilediği düşünülen mikro faktörler; varlık yapısı, aktif karlıık oranı, likidite oranı, finansal kaldıraç oranı, büyüme fırsatı, firma büyüklüğü ve piyasa değeri ile; makro değişkenler ise altın fiyatı, enflasyon oranı ve faiz oranı ile temsil edilmiştir. Bu doğrultuda, BIST’te payları sürekli olarak işlem gören ve mali sektörde faaliyet göstermeyen firmaların 2010-2016 yılları arasındaki verileri, panel veri analiz yöntemi ile incelenmiştir.

Yapılan analizler neticesinde, oluşturulan modelin bir bütün olarak \%99 güven aralığında anlamlı olduğu ve bağımsız değişkenlerin bağımlı değişkende meydana gelen değişimin \%34'ünü açıkladığı tespit edilmiştir. Modelde yer alan açıklayıcı değişkenlerin olasılık değerleri incelendiğinde, nakit kar payı dağıtım oranı ile varlık yapısı arasında istatistikî olarak anlamlı ve negatif ilişki belirlenmiştir. Firmaların varlık yapılarındaki bir birim değişim nakit kar payı dağıtım oranında yaklaşık 0.36 birimlik azalışa neden olmaktadır. Firmaların maddi duran varlıklarındaki azalış, daha düşük kar payı ödemesi yapılmasına neden olmaktadır. Bu bulgu, nakit kar payı dağıtım politikası ile kar payı dağıtım teorileri arasındaki öngörüler doğrultusunda, sinyal teorisi ve temsil maliyeti teorisini desteklediği söylenebilir. Ayrıca elde edilen bu bulgu, Al Shubiri (2011), Labhane ve Mahakud (2016), Sheikh vd. (2016) ve Sasu vd. (2017) tarafından gerçekleştirilen çalışmalarda elde edilen bulgular ile benzerlik göstermektedir. Dolayısıyla çalışmada test edilen hipotez 4 kabul edilmektedir.

Nakit kar payı dağıtım oranı ile aktif karlılık oranı arasında istatistikî olarak anlamlı ve pozitif ilişki belirlenmiştir. Firmaların aktif karlılı̆̆ındaki bir birim değişim nakit kar payı dağıtım oranında yaklaşık 1.29 birimlik artışa yol açmaktadır. Diğer taraftan firmaların karlııı düzeyleri arttıkça daha fazla kar payı ödemesi yapabildikleri de söylenebilir. Bu bulgu, sinyal teorisi ve temsil maliyeti teorisini desteklemektedir. Ayrıca elde edilen bu bulgu, Amidu ve Abor (2006), Al Malkawi (2007), Afza ve Mirza (2010), Imran (2011), Al Shubiri (2011), Yıldız vd. (2014), Labhane ve Mahakud (2016), Sheikh vd. (2016), Khan ve Ahmad (2017), Alber ve Alhabtour (2017) tarafından gerçekleştirilen çalışmalarda elde edilen bulguları desteklemektedir. Dolayısıyla çalışmada test edilen hipotez 5 kabul edilmektedir.

Analiz sonucunda elde edilen bir diğer bulgu ise, nakit kar payı dağıtım oranı ile finansal kaldıraç oranı arasındaki istatistikî olarak anlamlı ve pozitif yönlü ilişkidir. Firmaların finansal kaldıraç oranındaki bir birim değişim nakit kar payı dağıtım oranında yaklaşık 3.29 birimlik artışa yol açmaktadır. Yüksek kar payı dağıtımı yapan firmaların sermaye yapılarını oluşturmada yabancı kaynaklardan daha fazla yararlandığı ifade edilebilir. Diğer bir ifadeyle, nakit kar payı dağıtım oranı yüksek olan firmaların daha fazla borçlandıkları ve finansman ihtiyaçlarını yabancı kaynaklardan finanse ettikleri söylenebilir. Bu bulgunun, eldeki kuş teorisi ve vergi etkisi teorisini desteklediğini söylemek mümkündür. Ayrıca elde edilen bu bulgu, Sanjari ve Zarei (2014), Banerjee (2016) ve Sheikh vd. (2016) tarafından yapılan çalışmalarda elde edilen bulgular ile benzerlik göstermektedir. Ancak literatürde kar payı dağıtım oranı ile finansal kaldıraç arasında ağırlıklı olarak negatif ilişkinin varlığı ortaya çıkarılmıştır. Bu bağlamda çalışmada elde edilen anlamlı ve pozitif ilişki, literatür ile farklılık göstermektedir. Dolayısıyla çalışmada test edilen hipotez 9 kabul edilmektedir.

Nakit kar payı dağıtım oranı ile büyüme fırsatı arasında istatistikî olarak anlamlı ve negatif ilişki tespit edilmiştir. Büyüme fırsatındaki bir birim değişim nakit kar payı dağıtım oranında yaklaşık 0.31 birimlik azalışa sebep olmaktadır. Diğer bir deyişle, firmaların satışlarında yaşanan değişim nakit kar payı dağıtım oranında düşüşe neden olmaktadır. Bu bulgu, sinyal ve temsil maliyeti teorilerini desteklemektedir. Ayrıca elde edilen bu bulgu, literatürde daha önce gerçekleştirilen Amidu ve Abor (2006), Gill vd. (2010), Komrattanapanya (2013), Sanjari ve Zarei (2014), Kuzucu (2015), Khan ve Ahmad (2017) çalışmalarda elde edilen bulgular ile paralellik göstermektedir. Bu bulgu doğrultusunda çalışmada oluşturulan ve test edilen hipotez 12 kabul edilmektedir.

Çalışmada elde edilen bir başka bulgu da nakit kar payı dağıtım oranı ile firma büyüklüğü arasındaki anlamlı ve negatif ilişkidir. Firma büyüklüğündeki bir birim değişim nakit kar payı dağıtım oranında 0.80 birimlik azalışa neden olmaktadır. Kar payı dağıtım 
oranı yüksek olan firmalarda otofinansman düzeyinin düşük olması, yatırıma yönlendiren kaynak miktarının az olmasına sebep olmaktadır. Dolayısıyla daha yüksek kar payı ödeyen ve daha az yatırım yapan firmalarda büyüklük daha düşük düzeyde ve azalma eğiliminde olacaktır. Bu bulgu, eldeki kuş ve vergi etkisi teorileri destekler niteliktedir ve Ahmed ve Javid (2008), Afza ve Mirza (2010) tarafından yapılan çalışmalarda elde edilen bulgular ile benzerlik göstermektedir. Dolayısıyla hipotez 14 kabul edilmektedir.

Yapılan analiz neticesine piyasa değeri ile nakit kar payı dağıtım oranı arasında istatistikî olarak anlamlı ve pozitif ilişki ortaya çıkarılmıştır. Piyasa değerindeki bir birim değişim nakit kar payı dağıtım oranını 0.03 birim artırmaktadır. Diğer bir deyişle, piyasa değeri artan bir firmanın daha yüksek kar payı ödemesi öngörülmektedir. Piyasalarda yüksek kar payı dağıtımı gerçekleştiren firmalar, yatırımcılar tarafından daha fazla talep görmekte ve bu durum da firmanın piyasa değerini olumlu yönde etkilemektedir. Piyasa değeri ile kar payı dağıtım teorileri arasındaki ilişkiyi açıklamaya çalışan temel iki teori konumunda olan Modigliani ve Miller tarafından ortaya atılan ilintisizlik teorisi ve Gordon-Lintner tarafından desteklenen eldeki kuş teorisidir. Dolayısıyla elde edilen piyasa değeri ile nakit kar payı dağıtım oranı arasındaki pozitif ilişki, eldeki kuş teorisinin yanı sıra vergi etkisi teorisini de desteklemektedir. Bu bağlamda çalışmada test edilen hipotez 15 kabul edilmektedir.

Nakit kar payı dağıtım politikasını etkilediği tespit edilen son faktör, enflasyon oranıdır. Kar payı dağıtım politikasını etkileyen makro değişkenlerden biri olan enflasyon oranı ile nakit kar payı dağıtım oranı arasında istatistikî olarak anlamlı ve negatif ilişki belirlenmiştir. Enflasyon oranındaki bir birim değişim nakit kar payı dağıtım oranında 1.22 birimlik azalışa neden olmaktadır. Paranın satın alma gücünün düşmesi ve fiyatlar genel düzeyinin yükselmesi, firmaların kazançlarının değerinde düşüşe yol açmakta ve daha az kar payı ödemesi yapmalarına sebep olabilmektedir. Bu bulgu, müşteri etkisi ve ilintisizlik teorileri ile tutarlılık göstermektedir. Dolayısıyla hipotez 20 kabul edilmektedir.

Analiz sonucunda elde edilen bulgular genel olarak incelendiğinde, nakit kar payı dağıtım politikasına etki eden mikro faktörlerin, varlık yapısı, aktif karlııı oranı, finansal kaldıraç oranı, büyüme fırsatı, firma büyüklüğü olduğu belirlenirken; nakit kar payı dağıtım politikasına etki eden makro faktörlerin ise enflasyon oranı ve piyasa değeri olduğu belirlenmiştir. Dolayısıyla çalışma kapsamında oluşturulan hipotez 1 ve 2 kabul edilmektedir.

Çalışmada, nakit kar payı dağıtım politikasını etkileyen faktörlere ilişkin bulgulara karşın, likidite oranı ile nakit kar payı dağıtım oranı arasında istatistiki olarak anlamlı herhangi bir ilişki tespit edilememiştir. Bu bulgu, Imran (2011), Mehta (2012) ve Komrattanapanya (2013) tarafından yapılan elde edilen bulgular ile paralellik göstermektedir. Diğer taraftan altın fiyatı ve faiz oranı ile nakit kar payı dağıtım oranı arasında istatistikî olarak anlamlı bir ilişki bulunmamıştır. Bu doğrultuda çalışmada test edilen hipotez 7, 8, 17, 18, 21 ve 22 reddedilmektedir.

Firmaların varlıklarını devam ettirebilmelerinde kritik öneme sahip olan finansman ve yatırım kararlarının yanı sıra kar payı dağıtım kararları da firmaların geleceği açısından son derece önemlidir. Çalışmada, nakit kar payı dağıtım politikası ile firma değeri arasındaki pozitif ilişki doğrultusunda, elde edilen bulguların, başta yatırımcılar olmak üzere firmada karar verici ve uygulayıcı konumda olan yönetim kuruluna ve üst düzey yönetim kademesine yol gösterici nitelikte olduğu düşünülmektedir. Yöneticiler açısından kar payı dağıtım politikası oluşturulurken, kar payı dağıtım oranını etkilediği tespit edilen mikro ve makro faktörlerin dikkate alınarak karar alınması firmanın uzun vadede değerini olumlu yönde etkileyecektir. Yatırımcılar açısından ise elde edilen bulgular, yatırım yapacakları firmaların seçiminde, kaynaklarını etkin ve verimli şekilde değerlendirebilmelerinde yatırımcılara önemli bilgiler sunmaktadır.

Bu çalışmada, BIST 100 Endeksi'nde devamlı olarak işlem gören ve mali sektörde faaliyet göstermeyen firmaların nakit kar payı dağııım politikalarına etki eden mikro ve makro faktörler panel veri yöntemi ile analiz edilmiştir. Çalışmada nakit kar payı dağıtım oranına odaklanılması, kar payı dağıtım politikasına etki eden mikro ve makro faktörlerin bir arada incelenmesi gibi faktörler doğrultusunda çalışmanın konuyla ilişkili diğer çalışmalardan ayrıştığı düşünülmektedir. Bu çalışma, nakit kar payı ödemelerinin yanı sıra bedelsiz kar payı dağıtımları ve pay geri alımlarının birlikte ele alındığı kar payı dağıtım politikalarına etki edebilecek farklı mikro ve makro değişkenlerin analize dâhil edilmesi, farklı endekslerin ve dönemlerin incelenmesi, gelişmekte olan diğer ülkelerin endeksleri ile kıyaslama yapılması ve farklı ekonometrik yöntemlerin kullanılması suretiyle sonraki çalışmalarca geliştirilebilir. 


\section{KAYNAKLAR}

Afza, T., Mirza, H. H. (2010). Ownership structure and cash flows as determinations of corporate dividend policy in pakistan. International Business Research, 3 (3), 210-221.

Ahmed, H., Javid, A. Y. (2008). Dynamics and determinants of dividend policy in Pakistan (evidence from Karachi stock exchange non-financial listed firms). International Research Journal of Finance and Economics, 25, 148-171.

Alber, N., Alhabtour, A. (2017). Determinants of dividend policy in Saudi listed companies. Available at SSRN: https://ssrn.com/abstract=2909270, 1-10.

Al-Malkawi, H. A. N. (2007). Determinants of dividend policy in jordan: an applications of the tobit model. Journal of Economic and Administrative Sciences, 23 (2), 44-70.

Al-Shubiri, F. N. (2011). Determinants of changes dividend behavior policy: evidence from the amman stock exchange. Far East Journal of Pyschology and Business, 4 (2), 1-15.

Amidu, M., Abor, J. (2006). Determinants of the dividend payout ratio in Ghana. The Journal of Risk Finance, 7 (2), $136-145$.

Anil, K., Kapoor, S. (2008). Determinants of dividend payment ratio a study of Indian Information technology sector. International Research Journal of Finance and Economic, 15, 63-71.

Banerjee, S. (2016). Determinants of dividend policy for select Information technology companies in ındia: an empirical analysis, Parikalpana: KIIT. Journal of Management, 12 (2), 152-157.

Borsa İstanbul (2017). Endeksler.www.borsaistanbul.com.

Ceylan, A., Korkmaz, T. (2017). İşletmelerde Finansal Yönetim. 15. Baskı, Bursa: Ekin Basım Yayın Dağıtım.

Diacogiannis, G. P. (1993). Financial management a modelling approach using spreadsheets. McGraw-Hill.

Erdaş, M. L. (2017). Kar payı dağıtım politikasını etkileyen işletmelere özgü faktörlerin belirlenmesi: borsa istanbul-30 endeksi üzerine bir uygulama. Journal of Life Economics, 12, 49-76.

Gill, A., Biger, N., Tibrewala, R. (2010). Determinants of dividend payout ratios: evidence from united states. The Open Business Journal, 3, 8-14.

Gordon, M. J. (1963). Optimal investment and financing policy. The Journal of Finance, 18 (2), 264-272.

Gujarati, D. (2003). Basic Econometrics. New York: McGraw Hill Book Co.

Gürsoy, C. T. (2014). Finansal Yönetim İlkeleri. İstanbul: Beta Basım Yayın.

Hair, J., Anderson, R. E., Tatham, R., William C. B. (1998). Multivariate data analysis. New Jersey: Prentice-Hall.

Harris, M., Raviv, A. (1997). The theory of capital structure. Journal of Finance, 46 (1), 297-355.

Imran, K. (2011). Determinants of dividend payout policy: a case of pakistan engineering sector. The Romanian Economic Journal, XIV, 41.

Jensen, M. C., Meckling, W. H. (1976). Theory of the firm: Managerial behavior, agency costs and ownership sturucture. Journal of Financial Economics, 3 (4), 305-360.

Kamuyu Aydınlatma Platformu (2017). Finansal tablolar. www.kap.org.tr.

Khan, A. F., Ahmad, N. (2017). Determinants of dividend payout: an empirical study of pharmaceutical companies of pakistan stock exchange (PSX). Journal of Financial Studies \& Research, (2017), 1-16.

Komrattanapanya, P. (2013). Factors influencing dividend payout in Thailand: A Tobit regresyon analysis. International Journal of Accounting and Financing Reporting, 3 (2), 255-268.

Korkmaz, T., Yıldız, B., Gökbulut, R. İ. (2010). FVFM'nin IMKB ulusal 100 endeksindeki geçerliliğinin panel veri analizi ile test edilmesi. Istanbul University Journal of The School of Business Administration, 39 (1), 95-105.

Kuzucu, N. (2015). Determinants of dividend policy: a panel data analysis for turkish listed firms. International Journal of Business and Management, 10 (11), 149-160.

Labhane, N. B., Mahakud, J. (2016). Determinants of dividend policy of Indian companies: a panel data analysis. Paradigm, 20 (1) 36-55.

Lintner, J. (1956). Distribution of incomes of corporations among dividens, retained earnings, and taxes. The American Economics Review, 46 (2), 97-113. 
Lintner, J. (1962). Dividends, earnings, leverage, stock prices and supply of capital to corporations. The Review of Economics and Statistics, 64 , 243-269.

Mehta, A. (2012). An empirical analysis of determinants of dividend policy - evidence from the UAE companies. Global Review of Accounting and Finance, $3(1), 18-31$.

Merkez Bankası (2017). Elektronik veri dağıtım sistemi. http://evds.tcmb.gov.tr/.

Miller, M. H., Modigliani, F. (1961). Dividend policy, growth and the valuation of shares. The Journal of Business, 34 (4), 411-433.

Musiega, M. G., Alala, O. B., Douglas, M., Christopher, M. O., Robert, E. (2013). Determinants of dividend payout policy among non-financial firms on nairobi securities exchange, Kenya. Internatıonal Journal of Scıentific \& Technology Research, 2 (10), 253-266.

Patra, T., Poshakwale, S., Ow-Yong, K. (2012). Determinants of corporate dividend policy in Greece. Applied Financial Economics, 22 (13), 10791087.

Sanjari, T., Zarei, B. (2014). The study factors influencing corporate dividend policy of financial and none-financial firms on companies listed in Tehran stock exchange. Research Journal of Finance and Accounting, 5 (21), 138-144.

Sasu, D., Abor, J. Y., Osei, A. K. (2017). Dividend policy and shareholders' value: evidence from listed companies in Ghana. African Development Review, 29 (2), 293-304.

Sheikh, N. A., Naz, S., Abbasi, M. N. (2016). Communal determinants of dividend policy and capital structure: evidence from Pakistan. Pakistan Journal of Social Sciences (PJSS), 36 (2), 771-780.

Tabachnick, B. G., Fidell, L. S. (2001). Using Multivariate Statistics. Boston: Allyn and Bacon.

Uwuigbe, O. R. (2013). Determinants of dividend policy: a study of selected listed firms in Nigeria. Manager Journal, 17, 107-119.

Van Horne, J. C., Wachowicz, J. M. (1997). Fundamentals of financial management. Prentice Hall.

Yıldız, B., Gökbulut, R. İ., Korkmaz, T. (2014). Firmalarda temettü politikalarını etkileyen unsurlar: BisT sanayi işletmeleri üzerine bir panel veri uygulaması. Ekonomik ve Sosyal Araştırmalar Dergisi, 10 (10), 185-206.

Yusof, Y., Ismail, S. (2016). Determinants of dividend policy of public listed companies in Malaysia. Review of International Business and Strategy. 